\title{
Askeri Modernleşme, Askeri Disiplin ve Din: Düzenli Kitle Orduları Çağında Osmanlı Ordusu'nda Tabur İmamları
}

\author{
Military Modernization, Military Discipline and Religion: \\ The Battalion Imams in the Ottoman Army in the Age of Mass \\ Standing Armies
}

\section{Mehmet Beşikçi}

\section{$\ddot{O} \mathbf{z}$}

Bu makale, 19. yüzyıl başlarından Osmanlı İmparatorluğu'nun sonuna uzanan süreçte, Osmanlı ordusundaki tabur imamlarını konu edinmektedir. Askeri modernleşme hamleleri askeri alanla din alanı ve ulema arasında bir kopuş gerçekleştirmekten ziyade, yeni bir ilişki biçimi şekillendirmiştir. Makalede askeri imamlık müessesesi, otoriter-merkeziyetçi devlet otoritesinin din alanı üzerinde kurmak istediği kontrol mekanizmasının askeri alandaki tezahürü bağlamında ele alınmaktadır. Makalede bilhassa, siyasi iktidarla ittifak halindeki din adamlarının sadece askeri modernleşme hamlelerini meşrulaştırıcı aktörler olarak kalmadıkları vurgulanarak, tabur imamlarının, modern kitle ordularının gerektirdiği askeri disiplin ve itaat anlayışının Osmanlı ordusunda pratiğe geçirilmesinde son derece kritik bir rol oynadıkları savunulmaktadır. Tabur imamlığı uygulamasının geçirdiği evrim, imamlardan beklenen vazifeler, barış ve savaş zamanı oynadıkları roller ve ordudaki gündelik hayatları arşiv kaynakları, tanıklıklar, hatıralar ve ilgili ikinci el malzemelerin 1şığında analiz edilmektedir.

Anahtar Kelimeler: Askeri Modernleşme, Osmanlı Ordusu, Askeri İmamlar, Askerler

\footnotetext{
Öğr. Gör. Dr., Yıldız Teknik Üniversitesi, Atatürk İlkeleri ve İnkılap Tarihi Bölümü, besikcim@gmail.com
}

Bu makale iThenticate sistemi tarafından taranmıştır.

Makale Gönderim Tarihi: 03.03.2016

DOI: $10.17550 /$ aid.15258 


\section{Abstract}

This article deals with the subject-matter of battalion imams in the Ottoman army from the early $19^{\text {th }}$ century through the end of the Ottoman Empire. Rather than causing a break between the military and the sphere of religion and ulema, the military modernization attempts actually shaped a new form of relationship between the two. The article focuses on the issue of military imams within the context of how the authoritarian-centralist state authority's desire to establish control over religion manifested itself in the military sphere. The article emphasizes that the role of the ulema who supported the political power was not all about legitimizing the military modernization attempts with an Islamic rhetoric; it argues that the battalion imams also played a crucial role in putting into practice the concepts of military discipline and obedience required by modern mass standing armies. In the light of archival documents, witness accounts, memoirs and relevant secondary literature, the article analyzes the evolution of the practice of employing imams in the military, the duties that were expected from them, the roles that they played during peacetimes and wartimes, and their daily lives in the army.

Keywords: Military Modernization, Ottoman Army, Militar Imams, Soldiers 


\section{Giriş}

19. yüzyıl Osmanlı modernleşme hamlelerini ilerlemeci ve oryantalist bir pencereden gören ve 20. yüzyılın son çeyreğine değin belli bir ağırlığı olan tarih yazımı artık ciddi bir revizyona tabi tutulmuş iken, benzer bir eleştirel revizyonun Osmanlı askeri modernleşme tarihi için aynı ölçüde geçerli olduğunu söylemek zordur. Bilhassa askeri modernleşme ile din alanı arasındaki ilişki hâlâ büyük ölçüde ilerlemeci varsayımlar ve klişeler üzerinden anlaşılmaya çalışılmaktadır.

Askeri modernleşme hamlelerini sosyo-politik alanla dirsek temasındaki bir askeri yeniden yapılanma süreci olarak değil de, bir tür "gerilikten kurtulma" adımı olarak gören bu görüşün temel yapıtaşlarından biri, modernleşmenin, tıpkı genel düzlemde dini kamusal alandan çıkarıp özel alana havale etmesi gibi, askeri işlerle din işlerini de birbirinden ayıran bir sekülerleşmeyi beraberinde getirdiği tespitidir. Dolayısıyla, Batılı ve Aydınlanmacı ideallerden beslenen 19. yüzyıl başındaki askeri modernleşme hamlelerinin, dinden (ve din adamlarından) büyük ölçüde arındırılan bir ordu teşkilatı ortaya çıkardığı varsayılmaktadır. Geleneksel ile modern arasında katı bir ayrım çizgisi çizen bu kurguya göre, askeri teknolojinin artık sanayi devriminden beslendiği, yeni subay sınıfının fenni bir müfredat uygulayan okullardan yetiştiği, ordunun kas gücü olan askerlerin onların yaşamını en ince ayrıntısına kadar planlayan modern kışlalarda talim ettirildiği bir askeri sistemde dinin rolü asgariye inmiş olmalıydı. Modernleşme paradigmasından neşet eden klişelere tepkisel yaklaşan ve kendisini daha muhafazakâr çizgilerde tanımlayan yaklaşımlar da aslında, en azından Osmanlı askeri tarihi söz konusu olduğunda, bu klişeleri tersinden doğrulamaktan öteye gidemedi. Türkiye'de daha ziyade popüler tarih alanında boy gösteren bu tür tepkilerin, Osmanlı askeri modernleşme hamlelerinin orduyu dinden arındırdığını varsayan modernleşmeci bakışa analitik eleştiriler yöneltmek yerine, dine yapıldığg varsayılan bu operasyona sitem etmenin ötesine geçemediği söylenebilir.

Hâlbuki başta Avrupa dünyanın pek çok başka yerinde olduğu gibi, Osmanl1-Türk askerî modernleşmesi de askeriyenin dinle irtibatını koparmamıştı. Yapılan şey, ordunun ve devletin din alanı ve din adamlarıyla kurduğu ilişkinin tarzını değiştirmekti. Otoriter modernleşmeci ve merkezileşmeci siyaset projesine paralel bir şekilde, 19. yüzyılın ilk çeyreğinde şekillenen Osmanlı askeri modernleşme adımları meşrulaştırıcı bir İslami söyleme hep ihtiyaç duydu ve bu ihtiyaç, kitlesel askeri seferberlik çağında artarak devam 
etti. Dolayısıyla, bu süreçte siyasi iktidar açısından görüşleri "makbul" addedilerek potansiyel müttefik olarak görülen ve kendileri de siyasi iktidara destek verme eğilimi gösteren din adamları böylesi bir İslami söylemi pratikte etkili k1lacak en önemli aktörlerdi.

$\mathrm{Bu}$ yazı, Osmanlı askeri modernleşmesi ile din alanı ve din adamları ilişkisi üzerine odaklanarak, Osmanlı askeri teşkilatı içerisinde istihdam edilen ve daha ziyade orta ve alt seviye din adamları olan askeri imamları ele alıyor. 19. yüzyıldan Osmanlı Devleti'nin sonuna değin, Batılı tarzda modern "talimli” bir ordunun teşkili ve muhafazası meselesinde İslami meşrulaştırmaya başvurulması sıkça karşımıza çıkan bir durumdur. Kritik askeri modernleşme adımları esnasında, siyasi iktidara destek veren üst düzey ulemanın İslami bir söylem kullanarak bu adımları meşrulaştırmaya çalıştığı tespitini kabul etmekle birlikte, bu yazının asıl vurgulamak istediği nokta, din adamlarının, sadece kriz anlarında siyasi-kamusal düzeyde meşrulaştırıcı aktörler olarak kalmadıkları, "tabur imamlığı” müessesesi aracılığıyla askeri teşkilat içerisinde modern askeri itaat ve disiplin anlayışının yerleşmesinde de önemli ve daimi bir işlevi yerine getirdikleridir.

Yazıda askeri imamlığın düzenli ordu çağında daimi ve kadrolu bir müessese haline nasıl geldiği ve 19. yüzyıldan 20. yüzyıla ne tür değişimler geçirdiğinin yanı sıra, askeri imamlara hangi vazifelerin yüklendiği, onların barış ve savaş zamanları ne tür rolleri icra etmeleri beklendiği ve bu beklentilere imamların ne tür tepkiler verdiği soruları arşiv belgeleri, tanıklıklar, hatıralar ve ilgili ikinci el literatür incelenerek cevaplanmaya çalışılmaktadır.

\section{Modern Talimli Ordunun Dini “Talim” ile Meşrulaştırılması}

İlk adımı III. Selim'in Nizam-1 Cedid projesiyle atılan, Alemdar Mustafa Paşa'nın kısa ömürlü Sekban-ı Cedid tecrübesiyle canlandırılmaya çalışılan, Eşkinci Ocağı projesiyle tekrar gündeme alınıp II. Mahmud'un Yeniçeri Ocağı'nı söndürmesiyle önü açılan Batılı modelde yeni bir "talimli" ordu kurma işi, aslında bir askeri değişim süreci olduğu kadar bir siyasi tasfiye hareketiydi. ${ }^{1}$ Kendisiyle ittifak eden devlet ricali ve ulemanın desteğiyle Ye-

\footnotetext{
1 Bu dönüşüm sürecini son derece ayrıntılı bir biçimde analiz eden Gültekin Yıldız, bu süreci "sosyo-politik bir tasfiye olarak askeri yeniden yapılanma" şeklinde tarif eder. Bkz. Gültekin Yıldız, Neferin Adı Yok: Zorunlu Askerliğe Geçiş Sürecinde Osmanlı Devleti' nde Siyaset, Ordu ve Toplum (1826-1839) (İstanbul: Kitabevi, 2009), 1. Bölüm. Yeniçeriliğin son dönemine odaklanan ve Osmanlı askeri tarihinde yeni talimli ordu kurma adımlarını ilerilik-gerilik kısıtlamasını aşarak, askeri-siyasi-sosyal alanları harmanlayarak çok-boyutlu bir şekilde analiz eden ayrıca iki değerli çalışma için bkz.
} 
niçeri Ocağı'nı lağveden II. Mahmud, "Frenk talimi”’2 prensibine dayandırılması hedeflenen Muallem Asakir-i Mansure-i Muhammediye ordusunu kurarak, dış ve iç düşmanlara karşı performansı daha yüksek, ama aynı zamanda padişaha "sadık ve mûti" bir ordu yaratmayı amaçlıyordu. ${ }^{3}$ Bu yeni ordunun, giderek daha dişli bir rakip haline gelen Rusya gibi "dış” düşmanlara karşı Osmanlı Devleti'ni daha iyi savunması bekleniyordu. Ama aynı zamanda “içeride," Mora İsyanı’ndaki gibi ayrılıkçı milliyetçi hareketlere karşı etkili bir isyan bastırma kuvveti, Osmanlı sultanına karşı giderek daha tehditkâr hale gelen Misır Valisi Mehmed Ali Paşa gibi politik figürleri etkisizleştirici, ortadan kaldırılıncaya kadar merkezi epey uğraştıran Yanya hâkimi Tepedelenli Ali Paşa gibi ayanların canlanmasını engelleyici ve payitahttaki siyasi iktidara karşı her türlü muhalif hareketi bastırıcı bir kontrol gücü de temin etmesi bekleniyordu. Merkezi otoriteyi güçlendirecek bu kuvvetin sadık ve itaatkâr olması kadar depolitize de olması gerekiyordu. ${ }^{4}$

Mehmet Mert Sunar, Cauldron of Dissent: A Study of the Janissary Corps, 1807-1826 (Doktora Tezi, Binghamton New York Eyalet Üniversitesi, 2006); Fatih Yeşil, Nizâm-ı Cedid'den Yeniçeriliğin Kaldırılışına Osmanlı Kara Ordusunda Değişim, 1793-1826 (Doktora Tezi, Hacettepe Üniversitesi, 2009).

2 Osmanlı askeri modernleşme adımlarının önemli bir ilham kaynağının, merkeze karşı giderek daha güçlü siyasi bir rakip haline de gelen Mısır Valisi Mehmed Ali Paşa'nın Batı modelinde tesis ettiği ordunun olması nedeniyle ve Yeniçeri Ocă̆ı'nın lağvından önce, gelecek muhtemel tepkileri yumuşatmak için, hedeflenen yeni talim sistemi "Mısır talimi”" şeklinde de tabir ediliyordu. Bkz. Yüksel Çelik, "Asâkir-i Mansûre Ordusu'nda Talim Sisteminin Değişimi ve Avrupalı Uzmanların Rolü (1826-1839)," Türk Kültürü Incelemeleri Dergisi, No. 39 (Güz 2008), s. 88.

3 "Bize bir takım asker lazımdır ki, emrimize râm, hükmümüze fermânber olub, padişâh 'ulufesi yiyüb, gice ve gündüz tüfeği elinde bıçağı belinde olub, dur dediğimiz vakit dura, git dediğimiz zaman gide, iktizâsına göre bir yerde beş sene bekleye ve cenk ma'arifetinden gayrı bir işi olmaya. Eğer bizim devletimizde ta'limli ve râbitalı ve müretteb kâfire mukâbil olacak kadar asker tedârik olursa, hîn-i hâcetde düşmana cevab virüb, yedi kralı fetheyleriz..." Sadriazam Koca Yusuf Paşa'dan III. Selim'e, alıntı yapan Yeşil, Nizâm-ı Cedid'den Yeniçeriliğin Kaldırılışına, s. 10. Ayrıca bkz. İsmail Hakkı Uzunçarşılı, "Sultan III. Selim ve Koca Yusuf Paşa," Belleten, 19. Cilt, no. 154 (Nisan 1975), s. 233-256.

4 II. Mahmud'un tahayyül ettiği ordunun, yeniçağ Avrupası'nda devlet-ordu ilişkisi için yapılan aşağıdaki tespitle paralel olduğunu söylemek abartı olmayacaktır: "Yeniçağ devleti ile daimi ordu (muvazzaf ordu), ayrılmaz bir bütün oluşturur. Hobbes'un Leviathan'1, şiddet uygulamayı kendi tekeline alarak, sosyal düzlemde herkesin herkesle savaşına barışçıl bir nokta koyar. Artık sadece tek bir komutanın bulunduğu ve savaşın sadece devletin işi olduğu yerde, feodallerin ve farklı inançlar taşıyan hasımların bitmek bilmez savaşları da nihayet son bulur. Şiddete başvurma tekeli demek, şiddetin araçlarına sahip olmak ve bunları kullanan insanları denetlemek demektir. Dolayısıy- 
Askeri yenileşme dönemini başlattığı kabul edilen II. Mahmud aslinda dinden vazgeçmeyi hiç düşünmemiş, kendi devlet ve ordu projelerinin muvaffakiyeti için yeni bir "makbul” din ve din adamları tanımı şekillendirmişti. Yeniçeriliğin kaldırılmasına paralel cereyan eden Bektaşi Tarikatı'nın siyasi-sosyal etkisinin tasfiye operasyonunun ardından, sultanla gönüllü (ve de yer yer zoraki) ittifak eden ulema, askeri değişsim sürecini meşrulaştırmanın yanı sıra siyasi iktidarın din alanı üzerindeki kontrol gücünü pekiştirmesine de katkıda bulunmuştu. Zira II. Mahmud din bürokrasisindeki kilit noktalara, kendi siyasi perspektifine itiraz etmeyecek din adamlarını getirirken, muhalif eğilimdekileri görevden uzaklaştırıyordu. ${ }^{5}$ Mesela Şeyhülislam Mekkizade Asım Efendi yeterince güvenilir bulunmadığı için Ekim 1825'te azledilmiş, yerine Kadızade Tahir Efendi tayin edilmişti. ${ }^{6}$

Hedeflenen bu askeri dönüşümün meşrulaştırılması İslami bir söylem üzerinden cereyan etmişti. III. Selim'in Nizam-1 Cedid projesini hakl1laştırmaya çalışan layihalardan, ${ }^{7}$ II. Mahmud dönemi askeri-siyasi projelerin bir nevi meşrulaştırma memuru gibi hareket eden Es'ad Efendi'nin Üss- $i$ Zafer' ine ${ }^{8}$ kadar, yeni ordunun neden gerekli olduğu sorusuna verilen başlica cevaplardan biri İslami “mukabele-i bi’l-misl” prensibiydi. Kuran'da

la, her zaman emre amade bir ordu yoksa, hükümdar da yoktur.” Ulrich Bröckling, Disiplin: Askeri Ittaat Üretiminin Sosyolojisi ve Tarihi, çev. Veysel Atayman, 2. bask1 (İstanbul: Ayrıntı Yayınları, 2008), s. 23.

5 Avigdor Levy, "The Ottoman Ulema and the Military Reforms of Sultan Mahmud II," Asian and African Studies, 7. Cilt (1971), s. 15; Uriel Heyd, "The Ottoman Ulema and Westernization in the Time of Selim III and Mahmud II," The Modern Middle East: A Reader içinde, A. Hourani, P. Khoury ve M.C. Wilson (ed.) (Berkeley: University of California Press, 1993), s. 34

6 II. Mahmud ayrıca, "mevâliden bazılarına payeler dağıtmayı, meşhur dersiâmların rütbe ve derecelerini arttırmayı ve umuma açı dini merasimlere katılmayı da ihmal etmedi." Yüksel Çelik, Şeyhü'l-Vüzerâ Koca Hüsrev Paşa: II. Mahmud Devrinin Perde Arkası (Ankara: Türk Tarih Kurumu, 2013), s. 257.

7 Osman Özkul, III. Selim Döneminde Osmanlı Ulemâsı ve Yenileşme Konusundaki Tutumlart (1789-1807) (Doktora Tezi, İstanbul Üniversitesi, 1997), s. 164. Nizam-1 Cedid'e dair layihalar hakkında bkz. Kemal Beydilli, "Küçük Kaynarca'dan Tanzimât'a Islâhât Düşünceleri," İlmî Araştırmalar: Dil, Edebiyat, Tarih İncelemeleri Dergisi, No. 8 (1999), s. 25-64. Ayrıca bkz. Kahraman Şakul, "Nizâm-1 Cedid Düşüncesinde Batılılaşma ve İslami Modernleşme," Dîvân: İlmî Araştırmalar Dergisi, No. 19 (2005/2), s. $117-150$.

8 Es'ad Efendi, Üss-i Zafer (Yeniçeriliğin Kaldırılmasına Dair), Mehmet Arslan (ed.) (İstanbul: Kitabevi, 2005). 
Nahl suresinin 126. ayetine ${ }^{9}$ dayandırılan bu ilkenin meali, Müslümanların kendilerine saldıran kâfir düşmanlara aynı silahlar ve yöntemlerle karşılık vermesinin gerektiği şeklinde yapılıyordu. ${ }^{10}$ Zira Osmanlı askeri gücünün zaafa uğraması ve Avrupalı rakipler karşısında "perişanlığının” temel sebebi olarak, Osmanlı askerlerinin "evvela zarûriyyat-ı diniyyesini ve fazilet- $i$ cihâdı ve uli'l-emrin emr-i dinde ve esna-yl harbde iradesine itaati farz olduğunu öğrenmeme[si]” ve "ulemâ-i izâmın re’y ü iftâsılla tertib olunmuş kavânin-i askeriyeye ri' âyet etmeme [si]" gösteriliyordu. ${ }^{11}$ Yeniçeriliğin kaldırılmasının siyasi atmosferde daha çok teolojik anlamıyla ön plana çıkarılan "mukabele-i bi'l-misl" prensibiyle, II. Mahmud'un siyasi teologları bir taraftan sıkça hadis, tefsir, siyer kitaplarına ve hatta Kuran'a referans vererek metafizik açıdan iktidarın icraatını meşrulaştırırken, diğer taraftan son derece aktüel bir gerçekliğe, Avrupa'da uygulanan talime referans veriyordu. ${ }^{12}$

Öte yandan, askeri modernleşme adımlarının dini bir söylemle nasıl meşrulaştırıldığı konusu kadar önemli olan ve bu yazının kendine gündem olarak seçtiği mesele, dini söylemin ve onun aktarıcısı orta-alt seviye ulema mensuplarının modern askeri disiplin ve savaş motivasyonunun arttırılması hususunda askeriye içerisinde daimi ve "kadrolu" elemanlar olarak istihdam edilmesi olgusudur. ${ }^{13}$ Söz konusu yeni model orduyu meydana getirecek in-

9 "Eğer ceza verecekseniz size yapılanın misliyle cezalandırın..." Nahl Suresi 126. Ayet, http://mushaf.diyanet.gov.tr/ (erişim tarihi 16.01.2016).

10 Es'ad Efendi'nin ifadeleriyle, “...ulemâ-yı 'izâmın vücûbuyla iftâ buyurdukları mukâbele-bi' l-mislin icrası ve bu münasebetle asâkir-i islamiyenin a' dâ-yı din üzerlerine gâlibiyetle selâmet-i dünya vü uhrâsıdır ve mukâbele-bi' l-mislin ma' nâsı, a' dâ-yı din meydan-ı ma' rekede ehl-i islam üzerine vesile-i galebe ittihâz eyledikleri hareket her ne ise cünûd-ı müslimin dahi ol sûretle mukâbele etmek demektir." Esad Efendi, Üss-i Zafer, s. 58. Misliyle karşılık verilecek düşman, Osmanlı bağlamında zaman zaman siyasileştirilerek, "â' da-yı dîn u devlete" karşı, yani din ve devlet düşmanlarına karşı şeklinde de ifade ediliyordu. Yıldız, Neferin Adı Yok, s. 134.

11 Es'ad Efendi, Üss-i Zafer, s. 17.

12 Yeşil, Nizâm-ı Cedid' den Yeniçeriliğ̈in Kaldırılışına, s. 44.

13 Askeri imamlar konusuna kısa ama önemli bir şekilde değinen Kemal Beydilli’nin çalışmasının bir yol açıcı olduğunu söylemek gerekir. Bkz. Kemal Beydilli, Osmanlı' da İmamlar ve Bir İmamın Günlüğ̈̈ (İstanbul: Yitik Hazine Yayınları, 2013), s. 23-30. Ayrıca, Mustafa Birol Ülker'in, kısa popüler tarih yazıları şeklinde kaleme aldığı yazıları da, konuya dikkat çekme açısından zikredilmeye değerdir. Bkz. Mustafa Birol Ülker, “Askeri İmamlar,” Tarih ve Medeniyet Dergisi, No. 61 (Nisan 1999), s. 61-62; Mustafa Birol Ülker, "Tabur İmamlığından Moral Subaylığına," Çanakkale 2015, No. 6 (Ağustos 2010), s. 18-25. 
san kitlesinin, heterojen bir savaşçılar topluluğundan modern ordular için gerekli talim (drill) ve terbiyeyi (discipline) almış "emir kulu" neferlere dönüştürülmesi işinde de "makbul din"e ve onun uygulayıcısı din adamlarına önemli bir askeri vazife yüklenmişti.

Tıpkı Avrupa'da 17. yüzyıldan itibaren ilk örnekleri belirmeye başlayan ve modern askeri disiplini sağlamanın en temel mekânı haline gelen "kışla" tasavvurunda Protestan/Püriten görüşlerin etkili bir rol oynaması veyahut kışla neferlerinin, şahsi çıkar peşinde koşmaktan tecrit edilmiş manastır keşişlerinden ilham alınarak şekillendirilmeye çalışılması gibi, ${ }^{14}$ Osmanlı yeni nizami ordusu için tahayyül edilen asker tipinin talim ve terbiyesinde de, dünyevi teknoloji ve askeri fennin yöntemleri kadar, siyasi iktidarın makbul gördüğü şekliyle bir İslami endoktrinasyondan (ve bu endoktrinasyonu icra edecek kadrolu din adamlarından) da istifade edilmek isteniyordu. Dolayısıyla, III. Selim ve II. Mahmud dönemlerinde gerek İstanbul gerekse de taşradaki kışlalarda camiler inşa edilmesi (ya da mevcutların tamir ettirilmesi), askerlerin kışla içerisindeki gündelik zaman planlamasının namaz vakitlerine göre yapılması ve askerlerin yanaşık düzen eğitimini andırır tarzda toplu halde namaz kılmaya mecbur tutulması veya Birgivi Risalesi okumaya/dinlemeye zorlanması ve onlara çeşitli vesilelerle vaazlar verilmesi gibi uygulamalar, padişahın politikalarına meşruiyet kazandırma ya da ulemayı reformlar tarafına çekme kaygılarından fazlasını içeren bir öneme sahipti. ${ }^{15}$ $\mathrm{Bu}$ önem, gerek Batı gerekse de modernleştirilmeye çalışılan Osmanlı askeri teşkilatının rasyonel ve kontrol edilebilir/hesaplanabilir bir yaşam evreni olarak tasavvur edilmesinde, ordunun kas gücü olan insan kitlesini askeri disipline tâbi tutmada dinin ve din adamlarının da kilit bir rol üstlenmelerinde

14 Gültekin Yıldız, “Ondokuzuncu Yüzyılın İki ‘Standardizasyon Ütopyası': Kışla ve Hücre Tipi Hapishane,” Türkiye Günlüğü, No. 112 (Güz 2012), s. 119. Mesela, 19. yüzyılın ikinci yarısında İngiltere' de olduğu gibi, ordunun "mümin Hıristiyan askerler" topluluğu olarak aksettirilmesi askerlerin motivasyonunu arttırdığı gibi, ordunun halk nezdindeki imajını da sağlamlaştırıyor, hatta 19. yüzyılın son çeyreğinde filizlenmeye balşayan anti-militarist fikirlere karşı bir kalkan işlevini görüyordu. Bkz. Jörn Leonhard, "Nation-building, War Experiences, and European Models: The Rejection of Conscription in Britain," Fighting for a Living: A Comparative History of Military Labour, 1500-2000 içinde, Erik J. Zürcher (ed.) (Amsterdam University Press, 2013), s. 528. Ayrica bkz. Olive Anderson, "The Growth of Christian Militarism in Mid-Victorian Britain," English Historical Review, No. 84 (1971), s. 46-72.

15 Yeşil, Nizâm-ı Cedid' den Yeniçeriliğin Kaldırılışına, s. 82-83. "Kumandanlarının emirlerine itaat eden asker ile Allah'ın emirlerine itaat eden âbid Müslüman tiplerinin idare tarafından birbirini tamamlayan paralel 'teslim alma evrenleri' olarak görüldüğü de söylenebilir." Yıldız, Neferin Adı Yok, s. 367. 
yatıyordu. Bu disiplinin aktarılması ve muhafazasında önemli aktörlerden biri yeni mütefennin zâbit ve talim çavuşu ise, diğeri de artık askeri imamdı.

\section{Askeri İmamlık Müessesesinin Kadrolu ve Daimi Hale Gelişi}

Osmanlı askeri teşkilatı içerisinde imam istihdamı uygulaması aslında askeri modernleşme hamleleriyle başlamış değildi. Yeniçeri Ocağı içerisinde de "ocak imamı" ve bunun yanı sıra beş müezzin bulunurdu. ${ }^{16}$ Ancak, Yeniçeri Ocağı'ndaki imamlar hem sayıca çok azdı, hem de iktidarın beklediği ve modern ordu sisteminin tahayyül ettiği türden bir disiplin tesisinin aktörü olmaktan ziyade, ocağın kendi içerisinden çıkan, bir anlamda ocağın kendi esprit de corps'unun bir parçası, onun cemaat kimliğinin pekiştiricisi rolünü oynayan bir figürdü. III. Selim ile başlayan ordu teşkilatında dönüşüm adımları, beraberinde yeni bir imam istihdamı uygulamasını da getirdi. Nizam-1 Cedid projesi dahilinde tesis edilen Levent Çiftliği’nde imam kadrolarına yer verilmeye başland $1 .{ }^{17}$ Nizam-1 Cedid'in yanı sıra Humbaracı ve Lağımc1 ortalarında imam istihdamı öngörüldü. ${ }^{18} \mathrm{Bu}$ imamlar "askerlere beş vakit namaz kıldırmak" görevinin yanı sıra, "ta'lim-i aka'id-i diniyye lâzıme-i guzzât-ı Íslam olmă̆la bunlara Birgivî Risâlesi'ni okutmak” işini görecekler, bunun karşılığında günde 80 akçe yevimye tahsisatı alacaklard1. ${ }^{19}$

Başarısız olan Nizam-1 Cedid projesinden sonra, ordu imamlılığ müessesesi II. Mahmud'un askeri modernleşme adımlarıyla yeni bir önem kazandı. Yeniçeri Ocağı'na son darbeyi vurma yolunda 1826 yılının Mayıs ayında gündeme gelen Eşkinci Ocağı layihasında, imam istihdamı meselesine ayrıntılı bir yer verilmişti. Es'ad Efendi'nin naklettiği Eşkinci layihasına göre,

16 "İmam-ı hazreti ağa ve ağa imamı yahud sadece ocak imamı denilen imam Yeniçeriler arasındaki medrese dersi görümüş olanlardan tayin edilirdi...imam hangi odaya tayin edilirse orası imam ortası ve imam da onun kumandanı sayılırdı. İmamlığa... ocağın orta camiindeki müderrisinden ders görmüş, ocaktan yetişmiş ağa kapusunda müezzinlik eden beş müezzinin en âlimi geçerdi.” İsmail Hakkı Uzunçarşı1lı, Osmanlı Devleti Teşkilâtından Kapıkulu Ocakları, I. Cilt: Acemi Ocağı ve Yeniçeri Ocağ l (Ankara: Türk Tarih Kurumu Basımevi, 1988), s. 232. Keza Osmanlı donanmasında da imam istihdamı 19. yüzyıl öncesinde de rastlanan bir uygulamaydı. Mesela, 17. yüzyıl sonlarında, Kapudâne-i Hümâyûnu mürettebatında daimi olarak imam kadrosunun yer almaya başladığı görülmektedir. Bkz. İdris Bostan, Osmanlı Bahriye Teşkilâtı: XVII. Yüzyılda Tersâne-i Âmire (Ankara: Türk Tarih Kurumu Basımevi, 1992), s. 182-184.

17 Beydilli, Osmanlı' da Imamlar, s. 23.

18 Başbakanlık Osmanlı Arşivi (BOA), Hatt-1 Hümayun, nr. 58412.

19 Beydilli, Osmanlı' da Imamlar, s. 23. 
Her bir ortaya İstanbul kadısı marifetiyle birer imam intihâb...olunmak ve imam efendiler akşamları klşlalarında mevcud bulunup neferat-l merkûmeye Kur'ân-l 'Azîmü'ş-şân ve 'ilm-i hâl talim etmek; ve neferat-ı mezkûre talim günleri tahsis olunan mahall-i talimde cemaatle edâ-i salât edib ba'dehu imam efendi ruzâ'en-lillahi ta'âlâ fatiha-i şerife kuraatiyle cümlesi talime şurû' etmek...20̈̈ngörülüyordu. Başka bir deyişle, ordu imamları ve icra edecekleri vazife, askerlere sadece ibadet ettirmekten ibaret görülmeyip, yeni ordunun "talim" sisteminin ayrılmaz bir parçası olarak kurgulaniyordu.

Eşkinci projesinin Yeniçeri isyanı nedeniyle krize girmesiyle birlikte hemen akabinde 16 Haziran 1826'da Yeniçeri Ocağı'nın lağvının ardindan tesis edilen Asakir-i Mansure-i Muhammediye Ordusu'nda, imam istihdamı konusu aynı önemde görülmeye devam etti ve pratiğe geçirilmeye başladı. 7 Temmuz 1826'da çıarılan ilk Kanunname-i Asâkir-i Mansure-i Muhammediye'de zikredildiği şekliyle, Mansure Ordusu başlangıçta, 8 tertipten meydana gelecek, her bir tertip 1526 nefer içerecek ve toplam 12.000 neferden oluşacak bir ordu olarak tasarlanmıştı. ${ }^{21}$ Her tertipte, toplamı 100 nefer olacak ve başında bir yüzbaşı bulunacak 12 "saf” yer alacaktı. Bu düzenleme, istihdam edilecek imam sayısını deyim yerindeyse biraz şişkin tutmuştu. Her bir safa "İstanbul kadısı ma'rifetiyle" bir muvazzaf imam atanacak, yani her tertipte 12 imam bulunacaktı. Neferler bu imamların öncülüğünde vakit namazlarını "cemâ'at ile edâ" edecek, kışla içinde inşa edilecek mekteplerde "günde birer nevbet Kur'an" ve "avâma lâzım olacak mikdar mesâ'il-i diniyye ve 'ilm-i hallerini ve ba'dehu Birgivî Risâlesini ta'lîm ve tefhîm" edeceklerdi. ${ }^{22}$ "Talim" kavramının neredeyse modern nizami ordu ile eşanlamlı sayıldığı bir askeri dönüşüm sürecinde, askeri teşkilat içerisindeki dini ibadet ve endoktrinasyon işlerinin de "talim" olarak tanımlanıyor olması dikkate değerdir. ${ }^{23}$

20 Es'ad Efendi, Üss-i Zafer, s. 23.

21 Askerî Kânûnâmeler (1826-1827), A. Yaramış ve M. Güneş (ed.) (Ankara: Asil Yayın, 2007), s. 46; Yıldız, Neferin Adı Yok, s. 174. Avigdor Levy ise bir tertibin, muhtemelen tertibin komutanı binbaşıyı da dahil ederek, 1527 kişiden oluşacı̆̆ını not etmiştir. Bkz. Avigdor Levy, The Military Policy of Sultan Mahmud II, 1808-1839 (Doktora Tezi, Harvard Üniversitesi, 1968), s. 179.

22 Askerî Kânûnâmeler (1826-1827), s. 47, 59.

23 Benzer uygulamaları, yukarıda zikrettiğimiz Avrupa ordularının yanı sıra, Batı dışı başka ordular ve farklı koşullarda da gözlemlemek mümkündür. Örneğin, 19. Yüzyılda Hindistan'da İngiliz sömürge yöneticileri, Müslüman neferlerden İngilizlerin 
Askeri imamlığın Mansure Ordusu'yla birlikte gerçek anlamda daimi ve sistemli bir kadro haline gelmesi orduda dini söylemi kontrol işini emirkomuta zincirine bağlamakla kalmıyor, medreselerden mezun olan gençlere sağlam bir iş kapısı da açıyordu. Zira askeri imamlık maaşıı bir istihdam alanıydı. Mansure Ordusu'na, kuruluşundan hemen sonra yaklaşık yüz imam atanmış ${ }^{24}$ ve bunlara aylık 30 kuruş maaş bağlanmıştı. ${ }^{25}$ Başlangıçta bu maaş, askeri imamların kendi kıyafetlerini kendilerinin karşılayacağ1 varsayılarak biraz düşük tutulmuştu. Şeyhülislam Kadızade Mehmed Tahir Efendi'nin ordu imamlarının kadro ve maaşları hakkında padişahla yazışmasının ve imamlar arasındaki hoşnutsuzluğun hissedilmesinin ardından, "imam efendilere bilâ-kisve tahsis kllınan otuzar kuruş mahiye dahi hâl ve haysiyetlerine nazaran kendilerine kifâyet etmeyeceği" ifadesiyle, Ağustos 1826' da "kisve-i behâ namıyla", yani elbise parası katkısı adı altında zamlandırılarmış ve 60 kuruşa çıkarılmıştır. ${ }^{26}$ Bir müddet sonra bu elbise temini işini de askeriye üzerine almış, 8 Ocak 1827 tarihli bir düzenlemeyle, muvazzaf askerlerin üniforması gibi ordudaki imamlara da standart bir kıyafet getirilmiştir. $^{27}$

Askeri imamlığın modern askeri teşkilatın ayrılmaz bir parçası haline gelmesi sürecindeki son halka, Osmanlı askeri modernleşmesinin ilk tanım-

istifade edebileceği etkin bir ordu meydana getirmek amacıyla, "kışla İslamı" olarak adlandırılan uygulamalara başvurmuştu. Bu tür uygulamaların başlıca amacı, İslami temaların askerlerde "disiplin, kendini vazifeye adama ve itaat/sadakat" duygularını güçlendirmesi için kullanılmasıydı. Bkz. Nile Green, Islam and the Army in Colonial India (Cambridge: Cambridge University Press, 2009), s. 136-149.

24 Levy, The Military Policy of Sultan Mahmud II, s. 213-214.

25 Askerî Kânûnâmeler (1826-1827), s. 52.

26 Askerî Kânûnâmeler (1826-1827), s. 61; Beydilli, Osmanlı' da Imamlar, s. 26; Levy, The Military Policy of Sultan Mahmud II, s. 186.

$27 \mathrm{Bu}$ yeni üniformalar sayesinde imamların, "talebeden ve fukarâ gürûhundan olarak asâkir-i mezkûrenin imamları oldukları fark" edilecekti. Bkz. Askerî Kânûnâmeler (1826-1827), s. 83-84. Ordu imamlarının yeni kiyafeti, "her sene birer adet molla kavuğu, birer destâr ve boy cebgânı biçiminde cebsiz astarsız birer çuka ve Manisa ve bunun emsâli alacadan bir dizlik ve çıka slkma ve ikişer gömlek ve gömlek aşı ve kırmızı serhadlı ayakkabı" ve kışın verilecek "birer kırmızı çizme ve her sen eskidikçe bolca yenli yağmurluklar ve bir münâsib zâbir kılıcı ve çanta ve mathara...” biçimindeydi. İmamların kıyafetine dair ayrıca bkz. Levy, The Military Policy of Sultan Mahmud II, s. 214-215; Yıldı, Neferin Adl Yok, s. 179; Halil İbrahim Erbay, "Imams in the Reformed Army of Mahmud II: Uniform Regulations from Ottoman Military Archives, c.1827," The Modern Middle East: A Sourcebook for History içinde, C.M. Amin, B.C. Fortna ve E. Frierson (ed.) (Oxford: Oxford University Press, 2006), s. 471-476. 
layıcı özelliklerini şekillendirecek düzenlemelere imza atan Koca Hüsrev Paşa'nın Temmuz 1827 yılında Serasker olmasıyla gerçekleşmiştir. ${ }^{28}$ Hüsrev Paşa, genel çerçeve olarak Fransız ordu örgütlenmesini model olarak almış ve yeni ordunun ana taktik-operatif birimini "tabur" olarak kurgulamıştı. Buna göre, başlangıçta uygulanan, 12 saftan oluşan tertip birimi terk ediliyor, bunun yerine, her biri ortalama 100'er kişi içerecek 8 bölükten oluşan taburlar getiriliyordu (3 tabur ise bir "alay" meydana getirecekti). ${ }^{29} \mathrm{Hüsrev}$ Paşa düzenlemeleriyle birlikte, orduda istihdam edilen imam sayısı da revizyona tâbi tutuldu. Başlangıçta bir tertipte 12 imam şeklindeki oldukça şişkin tutulan imam sayısı azaltıldı. Bu önce bir tabura 4 imam seviyesine çekildi, daha sonraki dönemlerde ise her tabura bir imam standardına kavuştu. ${ }^{30}$

Mansure Ordusu'nun yanı sıra topçu, süvari, Cebhane-i Âmire, Bostanc1 ve hatta Mehterhane-i Âmire birliklerinde de imam istihdamına gidilmişti. ${ }^{31}$ Taşradaki yeni askeri örgütlenmenin ve spesifik olarak da askeri imamlık uygulamasının İstanbul'dakini esas alması istenmişti. ${ }^{32}$ Tabur imamları giderek ordu personel listelerinin, maaş cetvellerinin ve askeri teşrifatın ayrılmaz bir parçası oldu ve rollerinin önemi arttıkça askeri teşkilatın işleyişindeki konumları da sağlamlaştı. Mesela, bu tarihten itibaren ordu imamlarının maaşları hep belli bir seviyede seyretmiş̧ir. Abdülaziz devri ordu teşkilatına ait 1869 tarihli bir maaş cetvelinde, tabur imamının maaşı 250 kuruştur (bu maaş mülazım-1 evvelin, yani üsteğmenin maaşına eşittir).$^{33}$ Tabur imamlığı müessesesindeki en kapsamlı düzenlemelerden birinin, Balkan Harbi (1912-1913) yenilgisi sonrası Osmanlı ordusunda girişilen kapsamlı reformlarla birlikte yapıldığını söylemek mümkündür. Bu dü-

28 Çelik, Şeyhü'l-Vüzerâ Koca Hüsrev Paşa, s. 279.

29 Çelik, Şeyhü'l-Vüzerâ Koca Hüsrev Paşa, s. 290; Türk Silahlı Kuvvetler Tarihi, 3. Cilt, 5. Kısım: 1793-1908 (Ankara: Genelkurmay Basımevi, 1978), s. 190-191; Abdülkadir Özcan, "Asâkir-i Mansûre-i Muhammediye," TDV İslam Ansiklopedisi, 3. Cilt, s. 457-458.

30 Levy, The Military Policy of Sultan Mahmud II, s. 214; Beydilli, Osmanli' da Imamlar, s. 29. Bundan böyle, halk arasında da yaygın bilindiği şekliyle imparatorlun sonuna kadar, hatta erken Cumhuriyet devirlerinde, ordu imamları "tabur imamları" tabiriyle tanınır oldu.

31 Askerî Kânûnâmeler (1826-1827), s. 105, 127, 132, 149; Yıldız, Neferin Adı Yok, s. 352 .

32 Askerî Kânûnâmeler (1826-1827), s.66; Levy, The Military Policy of Sultan Mahmud II, s. 208.

33 Uğur Ünal, Sultan Abdülaziz Devri Osmanlı Kara Ordusu (1861-1876) (Ankara: Genelkurmay Basımevi, 2008), s. 141. 
zenlemeler alay ve tabur imamı olarak çalışacaklar için asgari eğitim şartları ve maaş ayarlamaları içeriyordu. ${ }^{34} 1914$ yılına gelindiğinde bir tabur imamının maaşı 900 kuruş olmuştur (aynı tarihte bir mülazım-ı evvelin maaşı ise 800 kuruştur). ${ }^{35}$ Askeri imamların özlük hakları kapsamında emeklilik hakk1 da $\operatorname{vard1} .^{36}$

Tabur imamlarının askeri teşkilattaki yeri zamanla tanımlı ve standart bir hale gelirken, 1871 yılındaki bir iradeyle alay imamları içerisinden imtihanla terfi edenlerin, şeyhülislamın da onayıyla, "alay müftüsü” olarak atanması uygulamasına geçilmiştir. ${ }^{37}$ Tabur imamı teşrifatta yüzbaşıdan önce geliyordu; her bir alayın birinci taburunun imamına "alay imamı" deniyordu. Alay müftüsü ise teşrifatta binbaşıdan önce geliyordu. Donanmada aynı işi yapan kişiye "gemi hocası" ya da "gemi imamı" deniyordu. Askeri eğitim kurumları, askeri hastaneler, kaleler ve askeri tersanelerde askeri imamlara rastlamak mümkündü. ${ }^{38}$

Osmanlı silahlı kuvvetleri teşkilat olarak genişledikçe ve sayısal olarak büyüdükçe, tabur imamı sayısı da ona paralel olarak sürekli artmıştı. Sayılara dair net istatistiki bilgiler hâlihazırda mevcut değilse de, bazı tahminler yürütülebilir. Osmanlı ordusunda bir taburun ortalama nefer sayısı genellikle 800 olarak planlanmıştı. ${ }^{39}$ Yani, aslında bir tabur imamının hitap etmesi beklenen insan sayısının azami 800 nefer olması öngörülmüştü. 1834

34 BOA, MV., 234 / 67, 1914.

35 Bkz. "Muhassasat-1 Askeriyye Kanun Layihasina Merbut Cetvel Suretidir (3 Haziran 1330/16 Haziran 1914)," Meclis-i Mebusan Kanun Layihaları, 1. Cilt (Ankara: TBMM Basımevi, 1992), s. 351-352.

36 Örneğin bkz. BOA, A.MKT.MHM., 404 / 65, 13 Nisan 1868; BOA, BEO, 3787 / 283995, 3 Ağustos 1910; BOA, BEO, 3788 / 284092, 5 Ağustos 1910; BOA, BEO, 4005 / 300306, 19 Şubat 1912; BOA, BEO, 4237 / 317756, 7 Aralık 1913.

37 BOA, İrade Dâhiliye, nr. 43592.

38 “Alay Müftüsü,” Mehmet Zeki Pakalın, Osmanlı Tarih Deyimleri ve Terimleri Sözlüğü, 1. Cilt (İstanbul: Milli Eğitim Bakanlığı Yayınevi, 1983), s. 46; Kemal Beydilli, "İmam," Türkiye Diyanet Vakfi Islam Ansiklopedisi, 22. Cilt, s. 181-186; Ziya Kazıc1, “Alay," Türkiye Diyanet Vakfı Íslam Ansiklopedisi, 2. Cilt, s. 347-348; Faruk Tut, Osmanlılar' da İmam-Hatiplik Müessesesi (Yüksek Lisans Tezi, Marmara Üniversitesi, 1991), s. 46-47; Ülker, “Askeri İmamlar,” s. 61-62.

39 Gültekin Yıldız, "Kara Kuvvetleri," Osmanlı Askerî Tarihi: Kara, Deniz ve Hava Kuvvetleri, 1792-1918 içinde, G. Yıldız (ed.) (İstanbul: Timaş, 2013), s. 53. Tabii bu sayı pratikte sıkça 800 'den daha az, nadiren de daha yüksek olabiliyordu. 
yılında Osmanlı nizami kara ordusunun mevcudu 36.386 iken $^{40}$ bu sayı 19. yüzyıl boyunca sürekli arttı ve 1868 'de 137.195 iken, 1900 yılında 250.242 oldu. ${ }^{41}$ Yani 20. yüzyıl başında sadece Osmanlı kara ordusunda en az 300 civarında askeri imamın görev yaptığını tahmin etmek mümkündür. Tabii asker sayısı açısından zirve noktası Birinci Dünya Savaşı yıllarıydı. Savaş boyunca Osmanlı silahlı kuvvetlerine alına toplam asker sayıs1 3 milyon s1nırına yaklaşmıştı. ${ }^{42} \mathrm{Bu}$ durumda, Birinci Dünya Savaşı'nda Osmanlı silahlı kuvvetlerinde görev yapan askeri imam sayısının genel toplamının 3 bini aştı̆̆ tahmin edilebilir.

\section{Tabur İmamlarının Rolleri: Beklenen ve İcra Edilen}

Askeri imamlardan beklenen vazifeler elbette Müslüman askerlere vakit namazlarını kıldırmak, Kuran okumak, temel din bilgisi öğretmek gibi, Müslümanların gündelik ibadetlerine yardımcı olma işinden ibaret değildi. Gerçi bu iş önemsiz değildi ve aslında II. Mahmud döneminden itibaren Osmanlı ordusunun kimlik tercihiyle yakından alakalıydı. Çok-dinli bir imparatorlukta, 1789 Fransız Devrimi sonrası milliyetçi fikirlerin yükselişe geçtiği bir dünyada II. Mahmud, merkezi iktidarını sağlamlaştırma doğrultusunda mümkün olduğunca tek kimlikli bir askeri güç oluşturmayı tercih etmişti. Mansure Ordusu, "Türk uşă̆ı" olarak adlandırılan Anadolulu Müslümanlar başta olmak üzere, imparatorluğun Müslüman nüfusundan toplanan bir ordu oldu. ${ }^{43} \mathrm{Bu}$ askeri-siyasi tercih II. Mahmud sonrası dönemlerde de devam etti. ${ }^{44}$ Elbette bu durum istisnaların hiç olmadığı anlamına gelmiyordu.

40 Türk Silahlı Kuvvetler Tarihi, 3. Cilt, 5. Kısım, s. 200.

41 Abdülhamid' in Seraskeri Rıza Paşa'nın Anıları, Mahir Aydın (ed.) (İstanbul: Kitabevi, 2012), s. 105.

42 Mehmet Beşikçi, Birinci Dünya Savaşı’nda Osmanlı Seferberliği (İstanbul: İş Bankası Kültür Yayınları, 2015), s. 121-122.

43 Virginia Aksan, Ottoman Wars 1700-1870: An Empire Besieged (Harlow: Longman, 2007), s. 357-358; Hakan Erdem, "Recruitment for the 'Victorious Soldiers of Muhammad' in the Arab Provinces, 1826-1828", Histories of the Middle East: New Directions içinde, I. Gershoni, H. Erdem ve U. Woköck (ed.), (Londra: Lynne Reinner Publishers, 2002), s. 189-206; Veysel Şimşek, The Grand Strategy of the Ottoman Empire, 1826-1841 (Doktora Tezi, McMaster Üniversitesi, 2015), s. 198-199.

$44 \mathrm{Bu}$ askeri-siyasi tercihin nedenleri ve sonuçlarına dair tartışmalar için bkz. Mehmet Beşikçi, "Mobilizing Military Labor in the Age of Total War: Ottoman Conscription before and during the Great War," Fighting for a Living: A Comparative History of Military Labour, 1500-2000 içinde, Erik J. Zürcher (ed.) (Amsterdam: Amsterdam University Press, 2013), s. 547-580. Bilindiği gibi, Tanzimat Fermanı'nda gayrimüslimlerin de askerlik kapsamına alınacağı deklare edilmesine karşın, pratikte Osmanlı 
Başta Balkan coğrafyasından olmak üzere, Osmanlı Devleti pratik ihtiyaçlar bastırdığında gayrimüslim cemaatlerden de belli dönemlerde askeri insan gücü olarak yararlanmaktan kaçınmıyordu. Hıristiyanlardan toplanan baltacı bölükleri, donanmada ihtiyaç duyulduğunda bilhassa Rumlardan nefer istihdamı ya da Silistre'de Hıristiyan Kazaklardan oluşturulan süvari birliği bu istisnalara örnekti. ${ }^{45}$

İstisnai durumlarda gayrimüslimlerden oluşan birliklere de, Müslümanların tabur imamı gibi din adamı istihdamı gündeme gelmişti. Mesela, Silistre'deki Kazak süvari birliğinde maaşlı rahiplerin istihdamı öngörülmüştü. ${ }^{46}$ Ancak, bu planların pratiğe tam olarak geçtiğini söylemek zordur. Mesela, 1847'de Kaptan-1 Derya Halil Rıfat Paşa'nın donanmadaki Hıristiyan Osmanlı neferleri için papaz tayini teklifi, dönemin şeyhülislamının görüşü alınarak reddedilmişti. ${ }^{47}$ Hatta tabur imamlığı Osmanlı ordusunun Müslüman kimliğinin ana sembollerinden biri olmuş, gayrimüslimlerin askere alınmamasının temel gerekçelerinden biri olarak gösterilebilmiştir. $\mathrm{Bu}$ yönde en güçlü vurgulardan biri, bu meselede devletin resmi bakışını yansıtan Ahmed Cevdet Paşa'dan gelmişti. Sayısal olarak asker sıkıntısı yaşanan Kırım Harbi seferberliğinden itibaren gündeme gelen, gayrimüslimlerden de asker alınması gerektiğine dair tartışmalarda Ahmed Cevdet Paşa son derece statükocu bir tavır almış ve tezini de ordudaki din adamlılığı müessesesi üzerine bina etmişti:

Tebe'a-yl gayr-ı müslimeden alınacak efrad-l askeriyye, neferat-ı İslamiyye ile mahlût [karışık] olursa, bir taburda imam olduğu gibi papas da

gayrimüslimleri 1909 yılındaki kanuni düzenlemeye kadar, "bedel-i askeri” karşılığında zorunlu askerlik sisteminin dışında tutulmuştur. Bkz. Ufuk Gülsoy, Osmanlı Gayrimüslimlerinin Askerlik Serüveni (İstanbul: Simurg, 2000).

45 Avigdor Levy, "The Contribution of Zaporozhian Cossacks to Ottoman Military Reform: Documents and Notes," Harvard Ukranian Studies, 6. Cilt, No. 3 (Eylül 1982), s. 372-413. Ama bu tür anlık uygulamalar sayısal olarak belli bir seviyeyi geçmediği gibi, 1909 yılına kadar herhangi bir hukuki mevzuat değişikliğine yol açmamış ve standart bir hale de gelmemiştir. Osmanlı silahlı kuvvetlerinde 19. yüzyıl boyunca çeşitli gayrimüslim gruplardan asker toplama örneklerine dair bkz. Tobias Heinzellman, Cihaddan Vatan Savunmasina: Osmanlı Imparatorluğu’nda Genel Askerlik Yükümlülüğ̈̈, 1826-1856, çev. Türkis Noyan (İstanbul: Kitap Yayınevi, 2009), s.210-215; Şimşek, The Grand Strategy of the Ottoman Empire, s. 208-210.

46 Yıldız, Neferin Adı Yok, s. 196; Heinzellman, Cihaddan Vatan Savunmasina, s. 210. 47 Gülsoy, Osmanlı Gayrimüslimlerinin Askerlik Serüveni, s 43-46. Belgeler için bkz. BOA, İrade, Mes. Müh., 363, 31 Ağustos 1847; BOA, İrade, Mes. Müh., 364, 4 Ekim 1847. 
bulundurmak lâzım gelir. Bir olsa, be'is yok, diyelim. Lâkin bizde tebe'a-yl gayr-ı müslimenin envâ-ı kesiresi var. Ortodoks, Katolik, Ermeni, Yakubi, Protestan... deyu muhtelif sınıflara münkasemdir... Bunlar hep başka başka papas isterler. Yahudiler de haham ister... Böyle mahlût bir heyet nasll idare olunacak? Ve kumandanların başı sıkıldı̆̆ zaman askerin ırk-ı hamiyyetini tahrik ile anları sabr u sebâta teşvik ve fevkalade fedakârlığa sevk içün belâgat-l askeriyyeye müracaat eyler. Ehl-i İslam içün bu bâbda en müessir olan sözler dahi "ya gazâ ya şehadet, haydi din-i mubin uğruna çocuklar" kelimatıdır... Mahlût bir taburun binbaşısı lede'l-hâce askeri gayrete getirmek içün ne diyecek? ${ }^{48}$

Tabur imamlarından beklenen vazifelerden muhtemelen daha önemlisi, askeri itaat üretmeye yapacakları katkıydı. Modern kitle ordularının sevk ve idaresinin aksamaması için, silahlı kuvvetlerdeki her askerin otoriteye mutlak itaati sağlanmalıydı. Ordular için hayati bir öneme sahip olan emir-komuta zincirinin etkin bir şekilde işlemesi bu itaatin sürekli ve yeniden üretilebiliyor olmasına bağlıydı. Modern çağda askeri disiplin kavramı, en başta bu itaat sisteminin canlı tutulması anlamına geliyordu. Yeniçerileri hep disiplinsizlikleriyle suçlamış bir askeri dönüşüm hamlesi için bu yeni disiplin anlayışı ayrıca bir önem arz ediyordu ve din adamlarından bu doğrultuda önemli bir katkı bekleniyordu. Bu katkı, Osmanlı İmparatorluğu'nda 1846 'da zorunlu askerlik sistemine geçildikten sonra çok daha hayati bir rol oynamaya başladı.

19. yüzyılda Osmanlı Devleti artan asker ihtiyacını karşılayabilmek için, ${ }^{49}$ Avrupa'da Napolyon Savaşları'yla (1803-1815) birlikte yaygın hale gelmeye başlayan "yurttaş ordusu" modelinden esinlenilerek, ahaliye zorunlu askerlik yükümlülüğü getirmiști. ${ }^{50} 19$. yüzyıl boyunca savaș olgusunun endüstriyelleşmesi ve kitle ordularına geçiş süreci bir yandan savaş seferberliklerinin kapsamını daha da büyütürken, bir yandan da zorunlu askerliği s1radan insanın gündemine sokma ve onu ikna etme hususunu daha da önemli kılıyordu. Ne var ki, ilk standart hukuki formatına 1846 Kura Kanunname-

48 Ahmed Cevdet Paşa, Ma' rûzât, Y. Halaçoğlu (ed.) (İstanbul: Çağrı Yayınları, 1980), s. $114-115$

49 Veysel Şimşek, “Osmanlı İmparatorluğu'nda Düzenli Ordu için Asker Toplanması: 1826-1853," Toplumsal Tarih, No. 198 (2010), s. 39-40.

50 Beşikçi, "Mobilizing Military Labor in the Age of Total War,"; Erik J. Zürcher, "The Ottoman Conscription System in Theory and Practice, 1844-1918", Arming the State: Military Conscription in the Middle East and Central Asia içinde, Erik J. Zürcher (ed.) (Londra: I.B. Tauris, 1999), s. 79-94. 
$\mathrm{si}^{51}$ ile kavuşan Osmanlı zorunlu askerlik sistemi, hep bir meşruiyet kriziyle baş etmek zorunda kalmıştı.

Hedef kitlesini ağırlıklı olarak Müslüman köylü erkeklerin oluşturduğu bu zorunlu hizmeti ahaliye kabul ettirmek aslında hiç kolay değildi. Osmanlı zorunlu askerlik sistemi, en başından Birinci Dünya Savaşı'nın sonuna kadar, ahalinin çeşitli biçimlerde gösterdiği dirençle baş etmek zorunda kalmıştır. Zira modern çağda "ordular sadece itaatkâr, cesur ve teknolojik becerilerle donanmış askerler" değil, "firariler, pasifistler, isyancılar, düşman saflarına geçenler ve kendi kendini sakatlayanlar" da imal etmiştir. ${ }^{52}$ Kırsaldaki gündelik ve zirai hayatı kesintiye uğratan zorunlu askerlik hizmeti, aralarında nüfus kayıt sisteminden sakınma, bakaya kalma, celbe icabet etmeme ve doğrudan askerden kaçma gibi çeşitli yöntemlerin yer aldığı bir ahali direnciyle karşılaştı. Bunun sonucunda, Osmanlı silahlı kuvvetlerinde disiplin arzu edilen seviyenin uzağında kalmıştı. Bu disiplini takviye etmek dünyevi nizamnamelerin ve cezaların işi olduğu kadar, askerliğin ve savaşın kutsallığına dair vaazlar verecek olan tabur imamlarının da işiydi.

Zorunlu askerliği halkın gündemine kanuni bir mecburiyet şeklinde sokmak ve askerden kaçanlara ağır cezalar koymak elbette etkisiz değildi. Ama kanuni zorunluluk, kapsamlı bir seferberliği tek başına mümkün kılmaya artık yeterli olmuyordu. İnsanları sadece askere gitmeye değil, görev bitene kadar zor şartlarda askerde kalmaya ve ölüm riskini kabullenmeye de ikna etmek gerekiyordu. 19. yüzyılda yükselişe geçen milliyetçi sloganlar askeri itaat açısından belli bir katkı sağlasa da, hiçbiri savaşta ölümü "şehadet” olarak tanımlayan dini söylemler kadar etkili olamıyordu. Dolayısıyla, ordudaki din adamları dünyada olduğu gibi ${ }^{53}$ Osmanlı Devleti’nde de askeri açıdan son derece önemli idiler.

Peki, tabur imamları kendilerinden beklenen bu rolü hangi araçlarla ve yöntemlerle icra edecekti? Bir tabur imamı, hedef kitlesi olan neferlerle nasıl bir dille iletişim kuracak ve bu iletişimde ne tür materyaller kullanacaktı? Zaman içerisinde çeşitli ufak çaplı revizyonlara uğramakla birlikte, bu araç ve yöntemleri genel olarak iki ana başlık altında toplamak mümkündür.

51 Musa Çadırcı, "Osmanlı İmparatorluğu'nda Askere Almada Kura Usulüne Geçilmesi: 1846 Tarihli Askerlik Kanunu," Askeri Tarih Bülteni, No. 18 (1985), s. 59-75.

52 Bröckling, Disiplin, s. 26-27.

53 Mustafa Sabri Sözeri, "Dünya Ordularında Din Terbiyesi ve Teşkilatı," İstanbul Yüksek İslam Enstitüsü Dergisi, No. 2 (1964), s. 93-164. 
Birinci kategoride, otorite tarafindan "makbul" addedilen dini bilgileri, bir askeri disiplin telkiniyle birlikte neferlere aktarmaya yardımcı olacak yazılı metinler bulunuyordu. Yukarıda da zikredildiği gibi, ordu imamlığı daha ilk gündeme geldiği anda, kullanılacak yazılı metin olarak Birgivi Risalesi seçilmişti. Birgivi (1523-1573) Osmanlı Sünni İslam geleneğinde itibarlı bir konuma sahipti ve muhtemelen, tasavvuf erbabına karşı mesafeli duruşu ve gündelik yaşamı düzenleyen ahlâki kaidelere yaptığı güçlü vurgu nedeniyle, ${ }^{54}$ sade dille yazmış olduğu ve bir tür kısa ilmihal niteliği taşıyan risalesi, ${ }^{55}$ askeri değişimi merkezi iktidar restorasyonuyla birlikte kurgulayan II. Mahmud için, askerlere yönelik "makbul” bir din öğretisi için tercih edilebilir türdendi. Yine askerlerin talim ve terbiyesi kapsamındaki dini eğitim için faydalı olabilecek bir başka el kitabı olarak, Yeniçeriliğin ilgası esnasinda Sultan II. Mahmud'a destek veren bir ulema mensubu olan İmamzade Esad Efendi (öl. 1851) ${ }^{56}$ tarafından şerh edilen Dürr-i Yektâ adlı eser çok sayıda basılarak dağıtılmıştır. ${ }^{57}$

Yüzyılın sonuna doğru ve bilhassa "10 Yıllık Harp" döneminde (1912-1922), bu metinlerin üretiminde sistemli bir artış yaşanmıştır. Bu neşriyat türü “Askere Din Kitabı” adını taşıyordu ve anafikir olarak “iyi asker iyi Müslüman, iyi Müslüman iyi asker olur” vurgusu yapıyorlard1..$^{58}$ Bilhassa II. Meşrutiyet döneminde sayıları artan ve Birinci Dünya Savaşı yıllarında özel bir önem atfedilen bu tür metinler, yine tahmin edilebileceği gibi dönemin Jön Türk siyasi iktidarıyla yakın duran veyahut en azından iktidara açıktan muhalefet etmeyen, "makbul” ulema mensupları tarafından yazıl1yordu. $^{59}$

54 Emrullah Yüksel, "Birgivî," Türkiye Diyanet Vakfı İslam Ansiklopedisi, 6. Cilt, s. 191-194.

55 Latin harflerine aktarılmış hali için bkz. İmamı Birgivî, Risâle-i Birgivî (Müminlere Nasihat) (İstanbul: Bedir Yayınevi, 1964).

56 Recep Cici, "İmamzâde Esad Efendi," Türkiye Diyanet Vakfı İslam Ansiklopedisi, 22. Cilt, s. 211-212.

57 Beydilli, Osmanli’ da Imamlar, s. 26.

58 İsmail Kara, "Cumhuriyet Devrinde Askere Din Dersleri: ‘İyi Asker İyi Müslüman, İyi Müslüman İyi Asker Olur',” Toplumsal Tarih, No. 166 (Ekim 2007), s. 48-53.

$59 \mathrm{Bu}$ neşriyatın bazı önemli örnekleri için bkz. Ömer Fevzi, Osmanlı Efradına Maneviyat-ı Askeriye Dersleri: Maneviyat Askerin Ruhudur (İstanbul: Mekteb-i Harbiye Matbaası, 1909); Ömer Fevzi, Maneviyat-ı Askeriye Makaleleri (İstanbul: Mekteb-i Harbiye Matbaas1, 1911); Ali Rahmi, Orduda Terbiye-i Maneviye ve Ruhiye (İstanbul: Ahmed İhsan ve Şürekası, 1911); Hüseyin Hakkı, Osmanlı Efradının Takviye-i Maneviyatı (İstanbul: Reşadiye Matbaası, 1914); Üryanizade Ali Vahid, Askerin İlmihali 
Ancak, okuryazarlığın son derece düşük olduğu Osmanlı ordusunda ${ }^{60}$ bu yazılı materyallerin, içeriklerinin tabur imamları rehberliğinde askerlere aktarılması bekleniyor olsa da, etkilerinin sınırlı kalmış olacağını tahmin etmek zor değildir. ${ }^{61}$ Dolayısıyla, ikinci kategori olarak, tabur imamlarının askerlerle iletişiminde aslında daha etkili olan araç ve yöntemler sözlü iletişim çerçevesi içinde olanlardı. Okuryazarlığın oldukça düşük olması, meşrulaştırıcı ya da propaganda amaçlı söylemlerin aktarımının ve etkisinin de illa düşük olacağı anlamına gelmiyordu. Zira sözlü iletişim araçları da en az yazılı iletişim kadar etkili olabiliyordu. Bu açıdan, çeşitli vesilelerle tabur imamlarının vaazlarının, dualarının, cephelerdeki tekbirlerinin ve hatta askerlerle günlük sohbetlerinde yaptıkları telkinlerin bu iletişimde son derece etkili bir rol oynadı̆̆ söylenebilir.

Zorunlu askerlik sistemi kapsamında askere alınan askerlerin askerliğe ikna edilmesi ve 1sındırılması hususunda imamlardan "nasihat" yardımı da istenebiliyordu. Bu tür uygulamaların özellikle celbe icabet konusunda sicili çok parlak addedilmeyen bölgelere yönelik gündeme geldiğini söylemek mümkündür. Mesela, 24 Nisan 1889 tarihinde, Bozcaada, Limni ve İstanköy gibi mıntıkalarda, "yeni askere alınanlara nasihat etmek üzere" birer tabur imamı tayin edilmesi kararı alınmıştı. ${ }^{62}$

Harbiye Nezareti bu sözlü iletişimin potansiyel etkisini ciddiye alıyordu. Bilhassa Birinci Dünya Savaşı'nda askerin savaşma gayretinin arttırılması hususunda komutanların tabur imamlarından beklentileri yüksekti. Bilhassa, artan firarların önlenmesi için, imamlardan askerden kaçmanın

(İstanbul: Ahmed İhsan ve Şürekası, 1917).

60 İmparatorluğun Müslüman nüfusundaki okuryazarlık oranı 20. Yüzyıl başlarında bile yüzde 10'u geçmezken, ezici çoğunluğu köylü gençlerden oluşan Osmanlı ordusundaki Müslüman askerlerin okuryazarlık oranı çok daha düşüktui. Bkz. Birinci Dünya Harbi' nde Türk Harbi, 1. Cilt: Osmanlı Imparatorluğu' nun Siyasi ve Askeri Hazırlıklarl ve Harbe Girişi (Ankara: Genelkurmay Basımevi, 1970), s. 227; Erik J. Zürcher, "Little Mehmet in the Desert: The Ottoman Soldier's Experience", Facing Armageddon: The First World War Experienced içinde, H. Cecil ve P. Liddle (ed.) (Londra: Leo Cooper, 1988), s. 230.

61 Kaldı ki, modernleşme hamlelerinin ilk safhalarında, bazen tabur imamlarının bizzat kendilerinin okuryazar olmaması gibi garip bir duruma da rastlanabiliyordu. 1838 yılında, tabur imamlarının okuryazar olmayan subay ve askerlere okuma-yazma öğretmesi vazifesini üstlenmeleri gündeme geldiğinde görüldü ki, imam kadrolarına vasıfsız elemanlar alındığı için pek çoğu okuryazar değildi. Beydilli, Osmanlı’ da İmamlar, s. 27.

62 BOA, MV., 42 / 61, 24 Nisan 1889. 
büyük bir günah olduğunu vurgulayan vaazlar vermeleri bekleniyordu..$^{63} \mathrm{Bu}$ konuyu büyük önem atfeden Harbiye Nezareti, taburlardaki imamların gerek sayı gerekse de donanım açısından tam yeterli olmadığını düşünerek ilave tedbir alma gereği duymuş, kendi bünyesinde bir imamlar heyeti oluşturarak cephelerdeki birliklere vaaz vermek üzere bunları cephelere yollamıştı. Bu "seyyar vaizler" cephelerdeki birlikleri dolaşarak firarların engellenmesi ve askerlerin yıpranmakta olan savaşma şevklerinin tahkim edilmesi için dini motifli ikna konuşmaları yapıyordu. Bu tür programlı vaazlara askerlerin katılımı zorunluydu. Bu vaazlar bir nevi toplu içtima havasında geçiyordu. Mesela, Sina-Filistin cephesinde Dramalı Osmanlı askeri Sami'nin (Yengin) günlüğündeki 15 Mayıs 1918 tarihli kaydında, "alay karargâhında bölükler toplattırılıp, Harbiye Nezareti tarafindan birliklere gönderilen bir vaiz tarafindan verilen vaaz dinlettirilmiştir" notu düşülmüştü. ${ }^{64}$

Böylesi vaazların askerler üzerinde nasıl bir etki yaptığını tam olarak anlamak, eldeki verilerin kısıtlı olduğu düşünülürse, kolay değildir. Bunları, uzayan savaş esnasında rutinleşen pek çok başka vazife gibi görev icabı esas duruşta dinleyip sonra gündelik işlerine aynı şekilde geri dönen askerler olabileceği gibi, gerçekten etkilenen ve heyecan duyan askerler de olabiliyordu. Mesela, Çanakkale Cephesi'nde görev yapan bir asker olan Emin (Çöl), hatıratında böyle bir sahneyi not etmiştir ve etkilendiği anlaşılmaktadır:

Bir din adaminin ziyareti. Belleğimde kalan adı Ahmet Hamdi idi. Uzun boylu, aksakallı, güler yüzlü idi. Öğüt vermek için derede toplandık. Derenin düşmana bakan yüzünde bir taşın üzerine çıktı. Bomba serisi, kurşun vizıltısı eksik olmuyordu. Bu sarıklı adam ürperti bile duymuyordu. Hz. Peygamberin bile savaştığını anlatıyor, "Çanakkale gibi hayati bir önemi olan bu kutsal savaşı yapan sizler ne büyük, ne mutlu kişilersiniz" gibi sözler ediyordu. ${ }^{65}$

Firarları engelleme tedbirleri içerisinde en önemli yeri şüphesiz cezalandırma oluşturuyordu ve bilhassa muharebe anında kaçarken yakalananla-

63 Bu konudaki örnekler için bkz. Birinci Dünya Harbi' nde Türk Harbi, 4. Cilt, 2. Klsım: Sina-Filistin Cephesi (Ankara: Genelkurmay Basımevi, 1986), s. 762; "30’uncu Tümen Sarıkamış Harekâtı Ceridesi (Hazırlık Safhası: 2 Ağustos - 20 Ağustos 1914),” Askerî Tarih Belgeleri Dergisi, No. 58 (Ocak 2009), s. 437.

64 Sami Yengin, Drama' dan Sina-Filistin' e Savaş Günlüğü (1917-1918) (Ankara: Genelkurmay Basımevi, 2007), s. 79.

65 Emin Çöl, Bir Erin Anıları: Çanakkale-Sina Savaşları, Celal Kazdağlı (ed.) (İstanbul: Nöbetçi Yayınları, 2009), s. 59. 
ra ya da kaçmaya birkaç kez teşebbüs etmiş olanlara verilen ölüm cezaları, ibret olsun diye diğer askerlerin gözü önünde asılma ya da kurşuna dizilme şeklinde gerçekleştirilebiliyordu. Genelde alay düzeyinde içtima edilerek gerçekleştirilen bu infazlarda, öldürülecek olan askerler için son dini merasimi yapmak üzere ordu imamları hazır bulunuyordu. ${ }^{66}$ İmamların bu kat1lımı, bir dini vecibenin yerine getirilmesi işi kadar, resmi otoritenin verdiği cezanın din adamları tarafından tasdik edildiği anlamına da geliyordu. $\mathrm{Bu}$ katılım, zorunlu askerlik hizmetini reddetmenin din kurumu tarafindan da mahkûm edildiğinin ve bu hususta din kurumunun resmi otoriteyle birlikte olduğunun sembolik bir dişavurumu olarak da görülebilir.

Resmi kararların böylesi sembolik tasdikini tabur imamlarının başka tavırlarında da görmek mümkündür. Bunların en dikkat çekici olanlarından biri, tabur imamlarının askerdeyken intihar edenlerin cenaze namazlarını kıldırmayı reddetmeleriydi. Osmanlı ordusunda askerlerin intihar vakalarına dair hâlihazırda güvenilir bir istatistiki bilgi mevcut değildir. Ama tanıklıklardan öğrendiğimiz kadarıyla, diğer ordularda olduğu gibi Osmanlı ordusunda da çeşitli nedenlerle intihar eden askerlere rastlanıyordu. Resmi otoritenin bakış açısından askerdeyken intihar bir tür askerden kaçma biçimiydi. Birinci Dünya Savaşı'nda Çanakkale ve Kafkas cephelerinde görev yapan ve hatıratında İttihatçı savaş politikalarına son derece eleştirel bir yaklaşım sergileyen, bu anlamda tabur imamlarını da sahici bulmayan Süleyman Nuri, eleştiri dozunu biraz da abartarak, şunları not etmişti:

Bizlere tabur imamlarl [tarafindan], uygun veya uygun olmayan her yerde ve her firsatta cephede şehit olmanın, yani nalları dikmenin meziyetinden bahsedilir ve bu gibilerin sorgusuz sualsiz cennete erişecekleri tefsir edilir ve müjdelenirdi... [İntihar eden askerler]... kendi keyifleriyle ölerek yurt vazifelerini ifadan kaçındıkları için, cennete gitmelerine layı görmemelerinden olacak ki, tabur imamları bu gibilerin defin merasimlerine bile uğramaya lüzum görmezdi. ${ }^{67}$

Tasdik edilmeyen bir başka davranış biçimi de askerdeyken kendini yaralama vakalarıydı. Yine resmi istatistiklere yansımamış olan bu sorunu tanıklıklardan bilebiliyoruz. Kendini bilerek yaralama ya da sakatlama da

66 Yengin, Drama' dan Sina-Filistin' e Savaş Günlüğ̈̈, s. 10.

67 Süleyman Nuri, Uyanan Esirler: Çanakkale Siperlerinden TKP Yönetimine (İstanbul: Türkiye Sosyal Tarih Araştırma Vakfı, 2002), s. 89, 93. Elbette, her kişisel anlatı gibi bu metin de, seçilen kelimelerden kullanılan üsluba kadar yazarının kendi kişisel tecrübeleri ve dünya görüşünün izlerini taşımaktadır. 
firar kapsamında değerlendirilen ve cezaya tâbi bir fiildi. İmamların, dini telkinlerle bu davranışın önlenmesine yardımcı olması isteniyordu. Meselâ, Kafkas cephesinde teğmen olarak hizmet ederken yaralanan ve tanıklıklarını tuttuğu günlüğe kaydeden Üsteğmen Celâl, Mayıs 1915'te cephedeki askerlerin kendilerini yaralama vakalarında bir artış gözlendiğini ve ölüm cezası da dahil olmak üzere sert cezaların fazla bir işe yaramadığını belirtmiş, soruna yönelik bir tedbir olarak kumandanların imamlardan askerlere her gün vaaz vermesini ve maneviyatlarını yükseltmesini istediklerini kaydetmişti. ${ }^{68}$

\section{Barışta ve Savaşta: Vazifenin Gündelik Yaşamında Tabur İmamları}

Ordunun daimi bir personeli olan tabur imamları diğer askerlerin maruz kaldığı tehlikelerin aynılarına açık haldeydiler. Savaşlardaki zayiatta tabur imamları da yer alıyordu. Yine mevcut resmi istatistikler net bilgiler sunmasa da, tanıklıklardan ve diğer ikinci el bilgilerden, savaş yıllarında hayatını kaybeden, yaralanan ve hatta esir düşen tabur imamları olduğunu görebilmekteyiz. Mesela, 26. Alay'ın Alay Müftüsü Hafız Mehmed Nazif Efendi Balkan Harbi'nde şehit olduktan sonra, Babaeski'deki evindeki eşyaları ve hayvanları "Bulgarlar tarafından tahrib ve gasp" edilmiş, bunun üzerine, babası tarafından verilen arzuhal üzerine, zararı tespit edilerek çocuklarına tazminat verilmişti. ${ }^{69}$ Savaşta hayatını kaybeden tabur imamlarına dair mevcut bilinen örneklerin büyük çoğunluğu tabii ki Birinci Dünya Savaşı yıllarına aittir. Mesela, Balkan Harbi’ne de katılmış, 97. Alay Müftüsü İsmail Hakkı Efendi 1915'te Kafkas cephesinde Köprüköy'de hayatını yitirmişti. Benzer zayiat tablosu sadece ordu için değil, Bahriye'de görevli din adamları için de geçerliydi. Mesela, Çanakkale'de batırılan Barbaros Hayreddin zırhlısında hayatını kaybedenler arasında gemi imamı Dadaylı Süleymanoğlu Mehmed Efendi de vardi. ${ }^{70}$

Görevdeyken vefat eden tabur imamlarının geride bıraktığı eşlerine maaş bağlanıyordu. Ama bu maaş zaman zaman o ailenin geçimini sağlamaya yetmediği için, tabur imamlarının eşleri maaş artışı talebi için dilekçeler verebiliyordu. Örneğin, 3. Ordu'ya bağlı 23. Alay'ın 1. Taburu'nun imamı Mehmed Tevfik Efendi, Yemen'de görevdeyken hayatını kaybettikten sonra eşi ve dört çocuğuna maaş bağlanmıştı. Ancak, Selanik’te ikamet eden eşi

68 Bir Teğmenin Doğu Cephesi Günlüğü: Üsteğmen Celal Bey’in Notları, Bahtiyar İstekli (ed.) (İstanbul: İş Bankası Kültür Yayınları, 2009), s. 153-154.

69 BOA, DH.H., 24 / 32, 22 Eylül 1914.

70 Ülker, “Tabur İmamlığından Moral Subaylığına,” s. 24-25. 
Nuriye Hanım, 1907 yılında, bu maaşın geçimlerini sağlamaya yetmediğinden arttırılmasını talep etmişti. ${ }^{71}$

Tabur imamları barış zamanı kışlalarda ve diğer askeri tesislerde askerlerin talim ve terbiyesinde kendilerinden beklenen vazifeleri yerine getirirken, savaş zamanı motive edici rolleri daha fazla ön plana çıkıyor, "askerin maneviyatını" yükseltici vaazlar ve telkinlerle cephedeki önemli aktörlerden biri oluyorlardı. Bununla birlikte, Osmanlı ordusu bilhassa 19. yüzyılın ikinci yarısı ve 20. yüzyıl başlarında sıkça bir “iç güvenlik” kuvveti olarak kullanılmış, ${ }^{72}$ isyan bastırma ve eşkıya takibi gibi gayrinizami harp operasyonlarında başta Balkanlar ve Yemen olmak üzere imparatorluğun çeşitli bölgelerine çok sayıda askeri birlik sevk edilmişti. Dolayısıyla, resmi askeri literatürde tanımlanan "barış" ve "savaş" zamanları dışında, aslında askeri birlikler ve personellerinin görev yaptığı üçüncü bir "melez” alan da bu gayrinizami harekât idi. Tabur imamları bu tür iç güvenlik operasyonlarında da, görev yaptıkları birliklerle beraber seyyar bir haldeydiler. ${ }^{73}$

İmamlar, muhtemelen muvazzaf zabitlikle din adamı olma arasında bulunmaktan kaynaklanan ve onlara belli bir itibar da getiren ikili konumları sayesinde, görev yaptıkları birliklerdeki sorunların üst makamlara bildirilmesinde bir nevi grup sözcüsü olarak öne çıkabiliyorlardı. Örneğin, 1902 yılının Ramazan ayında İştib’deki 36. Alay’ın müftüsü Arif Efendi, merkeze çektiği bir telgrafta, alay zabitanının Ramazan ayı da dahil olmak üzere dört aydır maaş alamadıklarından yakınmıştı. ${ }^{74}$ Bazen tabur imamları doğrudan kendi adlarına da taleplerde bulunabiliyordu. 3. Ordu bünyesinde 18. Alay'ın 3. Taburunda imamlık yapan Hacı Ali Raif Efendi bunlardan biriydi. Kendisi, taburuyla "keşf ü güzar ederken mahdumlarının tahsil-i ulûmdan" mahrum kaldıklarından bahisle, büyük oğlunu Mekteb-i Sultaniye "meccanen" kayıt ettirmek için 1891 yılında Seraskerlik kanalıyla Maarif Nezareti'ne başvuruda bulunmuş, ${ }^{75}$ ancak bu başvuru, Mekteb-i Sultani'nin

71 BOA, TFR.I.ŞKT., 128 / 12771, 2 Ekim 1907; ölen tabur imamının eşine bağlanan maaşın zamlanması hakkında başka bir örnek için bkz. BOA, DH.ID., 13-1 / 31, 22 Nisan 1911.

72 Beşikçi, “Başıbozuk Savaşçıdan 'Makbul' Tebaaya,” s. 88-91.

73 Örneğin, 1909 yılında 2. ve 3. Ordu içerisinden eşkıya takibi için görevlendirilen birliklerdeki tabur imamlarına değinmeler için bkz. BOA, DH.MKT., 2801 / 67, 4 May1s 1909.

74 BOA, BEO, 1773 / 132918, 3 Ocak 1902.

75 BOA, DH.MKT., 1833 / 3, 17 Mayis 1891. 
"meccanen sınıfında açık mahal olmadı̆̆gl" gerekçesiyle kabul edilmemişti. ${ }^{76}$

Ancak, bu itibarlı konumun her zaman sorunsuz işlediğini varsaymak da yanlış olacaktır. Tabur imamları görevleri müddetince çok çeşitli sorunlarla karşılaşabiliyordu. Otoritenin beklentileri açısından, icra ettiği vazifenin beklentileri karşıladığında ödül mekanizmasına mazhar olan tabur imamları olduğu gibi, beklentilerin altında kalanlara çeşitli yaptırımlar da uygulanabiliyordu. Bir uçta, görev yaptığı birliğin başarısında payı olduğu düşünülen tabur imamları, muvazzaf subaylar gibi, nişan ve madalyalarla taltif edilebiliyorlard. ${ }^{77}$ Diğer uçta ise, görevini istismar ettiğine hükmedilen veya beklenilen vazifeyi hakkıyla yerine getiremediği düşünülen tabur imamlarına yönelik meslekten ihraç kararları gündeme gelebiliyordu. Mesela, "asâkir-i şahane alay müftülerinden Şükrü Efendi” bunlardan biriydi. Bu şahıs 1898 yılında, "sû-i ahval ve harekâtından" dolayı meslekten ihraç edilmiş, 300 kuruş "maaş-ı mahlûlat" ile memleketi olan Kastamonu vilayetinin Boyabad kazasında ikamet ettirilmesine karar verilmişti. ${ }^{78}$ Meslekten ihraç edilen bir başka askeri imam, 16. Alay Müftüsü Arif Efendi idi. Kendisi verdiği dilekçede, rütbesine muadil bir mülkiye memurluğunda istihdam edilmek istemiş, ama kendisinin ancak Maarif Nezareti bünyesinde bir mevkide görevlendirilebileceği belirtilmişti. ${ }^{79}$ Zaman zaman da bazı tabur imamları kendi istekleriyle de istifa edebiliyorlardı. Mesela, askeriyede 12 sene imam olarak çalışmış olan Hüseyin Zeynel Efendi, 1903 yılında, 5. Ordu'ya bağlı seyyar topçu 27. Alay'ın 2. Taburu'nda görev yaparken istifasını istemişti. ${ }^{80}$

Eldeki örneklerin de işaret ettiği gibi, askeri imamların siyasi görüşleri açısından homojen bir kitle teşkil ettiğini varsaymak yanıltıcı olacaktır. Tabur imamlarının sayısı arttıkça ve ülkedeki siyasi görüş ayrılıkları derinleştikçe, askeri imamlar arasından da bu siyasi ayrışmada saf tutanlar olabiliyordu. Böylesi örneklere en çok Jön Türk muhalefetinin yükselişte olduğu zamanlarda rastlanılmaktadır. Bir tabur imamı eğer siyasi görüş olarak muhalifse ve bu muhalif tutum iktidar tarafından ortaya çıkarılmışsa,

76 BOA, DH.MKT., 1846 / 23, 1 Temmuz 1891.

77 Örnekler için bkz. BOA, İ.TAL., 234 / 66, 18 Aralık 1900; BOA, İ.TAL., 201 / 73, 19 Şubat 1900.

78 BOA, BEO, 1139 / 85360, 9 Haziran 1898; BOA, BEO, 1139 / 85361, 8 May1s 1901.

79 BOA, DH.MKT., 500 / 36, 10 Mayıs 1902.

80 BOA, Y.MTV., 250 / 66, 3 Eylül 1903. Başka istifa örnekleri için bkz. BOA, Y..MTV., 207 / 96, 15 Ekim 1900; BOA, BEO, 4206 / 315400, 18 Ağustos 1913. 
çeşitli tahkikat ve cezalara maruz kalabiliyordu. Sürgün bu tür cezaların en sık rastlananlarındand1. Mesela, "Saraçhane-i askeride" tabur imamı olan Mehmed Efendi, "bir daha Dersaadete gelmemek ve yedinci ordu-ı hümayunda istihdam edilmek üzere" 1889 yllında ailesiyle birlikte Yemen'e sürülmüştü. ${ }^{81}$ Benzer biçimde, muhtemelen Jön Türk hareketine sempatisi olan bir tabur imamı olan Eşref Efendi, 25 Mayıs 1902 tarihinde Manastır valisi Edib Paşa tarafindan saraya yollanan bir telgraftan öğrenildiğine göre, Debre Telgrafhanesini işgal eden bir grup ordu mensubu arasında bulunuyordu ve bu eylem nedeniyle sürgün cezası almıştı. ${ }^{82}$ Muhalifken böylesi cezalar alan tabur imamları, 1908'de meşrutiyetin yeniden ilanıyla birlikte Jön Türklerin iktidara geçmesinin ardından belli bir rahatlamaya kavuşmuştu. Örneğin, "mücrim-i siyasiyeden" olan 2. Frrka 5. Alay müftüsü Ali Osman Efendi, 1908'den sonra "bu kabil olanların afv-l umumiden müstefid olmalarl" sayesinde, verdiği dilekçe üzerine aftan yararlanıyor ve "iade-i rütbe" ile istihdam ediliyordu. ${ }^{83}$ Bununla birlikte, iktidara siyaseten yakın olmak da bazen tam güvence getirmiyor, bu gibi durumlarda askeri imamlar muhalif grupların şiddetine maruz kalabiliyor ve siyaseten taraf tutmak canlarına mal olabiliyordu. Örneğin, Jön Türk muhalefetinin Makedonya'da artık patlama noktasına geldiği 1908 yılında, Selanik’te konuşlu bir alayın müftüsü, Yıldız Sarayı'na bilgi aktardığı İttihad ve Terakki Cemiyeti tarafından öğrenildiğinde, genç bir subay tarafından 10 Temmuz 1908'de silahla vurularak öldürülmüştü. ${ }^{84}$

Öte yandan, orduda görev yapan tabur imamlarının kendilerinden beklenen vazifeleri hiç sorgulamadan benimsediğini ve tutumlarında hepsinin tamamen aynı davrandığını söylemek de doğru olmayacaktır. Tabur imamları geriye, hatıra ve günlük türü pek az kişisel kayıt bıraktığı için, bu tutumların çeşitliliği hakkında hâlihazırda fazla bilgi sahibi değiliz. Ama az sayıdaki örnekten anlaşılıyor ki, ordu içindeki sorunları tespit edip daha eleştirel görüşlere sahip imamlar da yok değildi. Mesela, bir medrese hocası iken Birinci Dünya Savaşı patlak verdikten sonra orduya gönüllü tabur imamı olarak katılan ve Çanakkale Cephesi'nde hizmet eden Abdullah Fevzi

81 BOA, Y.PRK.ASK., 56 / 96, 4 Ağustos 1889. Başka bir sürgün örneği için bkz. BOA, BEO, 4058 / 304283, 1 Temmuz 1912; BOA, MV., 227 / 144, 27 Haziran 1912. 82 BOA, Y.MTV., 230 / 90, 25 Mayıs 1902.

83 BOA, BEO, 3419 / 256395, 18 Ekim 1908.

84 M. Şükrü Hanioğlu, Preparation for a Revolution: The Young Turks, 1902-1908 (Oxford: Oxford University Press, 2001), s. 270 
Efendi, tanıklığını kaleme almış nadir imamlardan biriydi. Abdullah Fevzi Osmanlı ordusunda zabitlerin erlere kötü muamelelerini ve özellikle de sıkça dayağa başvurmalarını eleştiriyor, bu muamele tarzının askerlerin moralini ve aralarındaki birlik ruhunu zayıflatan başlıca nedenlerden biri olduğunu belirtiyordu. ${ }^{85}$

Tabur imamları savaş zamanı gerek cephe hatlarında, gerekse de cephe gerisindeki askeri birliklerde, savaş yıllarına özgü sosyal hayatın da bir parçasıydılar. Cephelerde giderek kötüleşen beslenme, giyinme ve barınma şartlarıyla baş etme sorunları imamların da maruz kaldığı bir durumdu. Halledilmesi gereken işlerin çok çeşitli ve çetrefil olduğu askeri birliklerde, imamlara "asli" görevlerinin dışında vazifeler verildiği de oluyordu. Örneğin, görev yaptıkları taburlar için mutemetlik yapma bunlardan biriydi. Birinci Dünya Savaşı'na ihtiyat zabiti (yedek subay) olarak katılan İ. Hakkı (Sunata), Gelibolu'ya giderken taburlarına gelen paraları tabur imamının alıp getirdiğini not etmişti. ${ }^{86}$ Taburlara yollanan gıda ve giyecekleri teslim alma işinde de imamlar karşımıza çıkabilmektedir. Bir başka örnekte, yukarıda da zikredilen Sami Yengin göre yaptığı Sina-Filistin Cephesi'ndeki taburuna yollanan "90 koyun, sekiz siğır, 59 okka şeker ve 65 kat elbise"den oluşan eşyayı istasyondan tabur imamı Hafız Mahmud Efendi teslim almışt. ${ }^{87}$

Öte yandan, gündelik hayatın bir parçası olma konusunu bir parça abartan ve askerlerin ihtiyaçlarını karşılama ihtiyacını kendine göre maişet kapısına çeviren imamlar da yok değildi. 1917 yılında Kafkas Cephesi'nde, iki dişi keçisi ile sütçülük yapıp askerlere "bir fincan sütü iki gümüş kuruşa satan" tabur imamı bunlardan biriydi. Buna tanıklık eden yedek subay İ. Hakkı Sunata'nın aktardı̆̆ına göre, bu davranışıyla askerlerin gözünde tepkiyle karışı alay konusu olan bu imamın keçilerini kurt kaptığında askerler, "zaylf, hasta askerlerin kesesinden imamin emdiği haram paraların cezasını keçileri ödedi" esprisini yapmışlardı. Aynı imam daha, savaşta Osmanlı ordusunun insan kayıplarında önemli bir rol oynamış olan salgın hastalıkların kurbanı olmuş ve tifoya yakalanıp ölmüştü. ${ }^{88}$

85 Abdullah Fevzi Efendi, Çanakkale Cephesinde Bir Müderris, A. O. Koçkuzu (ed.) (İstanbul: İz Yayıncilık, 2010), s. 129-130, 144, 170.

86 İ. Hakkı Sunata, Gelibolu’ dan Kafkaslara: Birinci Dünya Savaşı Anılarım (İstanbul: İş Bankası Kültür Yayınları, 2003), s. 93.

87 Yengin, Drama' dan Sina-Filistin'e Savaş Günlüğ̈̈, s. 109.

88 Sunata, Gelibolu' dan Kafkaslara, s. 400-401. 


\section{Sonuç}

Bu yazıda, Osmanlı ordusundaki tabur imamlığı müessesinin ve tabur imamlarının 19. yüzyıl başlarından Birinci Dünya Savaşı'nın sonuna uzanan süreçte eleştirel bir panoraması sunulmaya çalışılmıştır. Düzenli kitle orduları çağında, Osmanlı ordusunda imamların daimi olarak istihdamı, modernleşmenin askeri alanla din alanı ve din adamları arasında bir kopuş değil, yeni bir ilişki tarzı ortaya çıkardığının kanıtı olarak okunabilir. Ancak, bu ilişki otoriter-modernleşmeci siyasi iktidarla ittifak içerisindeki din adamlarının kriz anlarında askeri dönüşümleri İslami bir dil aracılığıyla meşrulaştırmalarından ibaret değildir. Askeri teşkilat içerisinde tabur imamı olarak istihdam edilen din adamlarının, modern ordunun askerlerinde itaat ve disiplin aşılamada da kilit bir rol oynaması beklenmiştir. Bilhassa zorunlu askerlik sistemi çağında, sıradan insanın toplumsal yaşamında erken yaşlardan itibaren karşılaştığı ve kendi bireysel anlam dünyasında önemli bir yeri olan dini referansların modern askeri itaat ve disiplinin tesisi ve muhafazası için kilit bir öneme sahip olduğu söylenebilir. Bu dini referansların askeri teşkilat içerisindeki aktarıcısı olan tabur imamlarının önemli bir vazifesi, askerlerin dini ibadetlerini yerine getirmesine yardımcı olmakla yetinmeyip, barış zamanı kışlalarda askerlerin zorunlu askerliğe ikna edilmesine ve rutin talim ve terbiyelerinin aksamadan yürütülmesine katkı yapmaktı. Sefer zamanları ise, askerin harbe sevk ve motivasyonunda olduğu kadar, bilhassa son dönem Osmanlı harplerinde neredeyse kronik bir hal alan firar sorununun önlenmesinde tabur imamlarının vaaz ve telkinler yoluyla oynadığı rolden otoritelerin beklentileri yüksek olmuştur. 


\section{Kaynakça}

\section{Birinci El Kaynaklar}

Arşiv Kaynakları Başbakanlık Osmanlı Arşivleri (BOA)

BEO(Bâb-1 ÂlîEvrak Odası)(3787/283995; 3788/284092;4005/300306;4237/317756; 1773/132918; 1139/85360;1139/85361; 4206/315400; 4058 / 304283; 3419/256395)

DH (Dahiliye Nezâreti Belgeleri) (DH.H., 24/32; DH.ID., 13-1/31; DH.MKT., 2801/67; DH.MKT., 1833/3; DH.MKT., 1846/23; DH.MKT., 500/36)

Hatt-1 Hümâyûnlar (58412)

İradeler (İrade-Dahiliye 43592; İrade- Mesâil-i Mühimme 363;364; İrade-Taltifat 234/66; 201/73)

MV (Meclis-i Vükelâ Mazbataları) (234/67; 170/59; 42/61; 227/144)

Sadaret Mektubi Mühimme Kalemi Evrakı (A.MKT.MHM., 404/65)

TFR.I.ŞKT. (Rumeli Müfettişliği Arzuhaller) (128/12771)

Y1ldız Sarayı Evrakı (Mütenevvi Maruzât, 250/66; 207/96; 230/90; Perakende Evrak Askeri Maruzât, 56/96)

\section{Basılı Arşiv Kaynakları}

Askerî Kânûnâmeler (1826-1827), A. Yaramış ve M. Güneş (ed.) (Ankara: Asil Yayın, 2007).

“30’uncu Tümen Sarıkamış Harekâtı Ceridesi (Hazırlık Safhası: 2 Ağustos - 20 Ağustos 1914)," Askerî Tarih Belgeleri Dergisi, No. 58 (Ocak 2009): $1-475$.

"Muhassasat-1 Askeriyye Kanun Layihasına Merbut Cetvel Suretidir (3 Haziran 1330/16 Haziran 1914)," Meclis-i Mebusan Kanun Layihaları, 1. Cilt (Ankara: TBMM Basımevi, 1992), 351-352.

\section{İkinci El Kaynaklar}

Pakalın, Mehmet Zeki. “Alay Müftüsü.” Osmanlı Tarih Deyimleri ve Terimleri Sözlüğü, 1. Cilt, 46. İstanbul: Milli Eğitim Bakanlığı Yayınevi, 1983.

Abdullah Fevzi Efendi. Çanakkale Cephesinde Bir Müderris. Ed.: Ali Osman Koçkuzu. İstanbul: İz Yayıncılık, 2010.

Abdülhamid'in Seraskeri Rıza Paşa'nın Anıları. Ed.: Mahir Aydın. İstanbul: 
Kitabevi Yayınları, 2012.

Ahmed Cevdet Paşa. Ma'rûzât. Ed.: Yusuf Halaçoğlu. İstanbul: Çăgrı Yayınlar1, 1980.

Aksan, Virginia. Ottoman Wars 1700-1870: An Empire Besieged. Harlow: Longman, 2007.

Ali Rahmi. Orduda Terbiye-i Maneviye ve Ruhiye. İstanbul: Ahmed İhsan ve Şürekâsı, 1911.

Anderson, Olive. "The Growth of Christian Militarism in Mid-Victorian Britain.” English Historical Review, 84 (1971): 46-72.

Beşikçi, Mehmet. "Mobilizing Military Labor in the Age of Total War: Ottoman Conscription before and during the Great War." Fighting for a Living: A Comparative History of Military Labour, 1500-2000 içinde. Ed.: Erik J. Zürcher. Amsterdam: Amsterdam University Press, 2013.

Beşikçi, Mehmet. Birinci Dünya Savaşı ’nda Osmanlı Seferberliği. İstanbul: İş Bankası Kültür Yayınları, 2015.

Beydilli, Kemal. “İmam,” TDV İslam Ansiklopedisi, 22. Cilt, 181-186.

Beydilli, Kemal. "Küçük Kaynarca'dan Tanzimât'a Islâhât Düşünceleri." İlmî Araştırmalar: Dil, Edebiyat, Tarih Incelemeleri Dergisi, 8 (1999): 25-64.

Beydilli, Kemal. Osmanlı'da Imamlar ve Bir İmamın Günlüğü. İstanbul: Yitik Hazine Yayınları, 2013.

Bir Tĕgmenin Doğu Cephesi Günlüğü: Üsteğmen Celal Bey'in Notları. Ed.: Bahtiyar İstekli. İstanbul: İş Bankası Kültür Yayınları, 2009.

Birinci Dünya Harbi’nde Türk Harbi, 1. Cilt: Osmanlı Imparatorluğu'nun Siyasi ve Askeri Hazırlıkları ve Harbe Girişi. Ankara: Genelkurmay Basımevi, 1970.

Birinci Dünya Harbi’nde Türk Harbi, 4. Cilt, 2. Klsım: Sina-Filistin Cephesi. Ankara: Genelkurmay Basımevi, 1986.

Bostan, İdris. Osmanlı Bahriye Teşkilâtı: XVII. Yüzyılda Tersâne-i Âmire. Ankara: Türk Tarih Kurumu Basımevi, 1992.

Bröckling, Ulrich. Disiplin: Askeri Itaat Üretiminin Sosyolojisi ve Tarihi. Çev.: Veysel Atayman, 2. Baskı. İstanbul: Ayrıntı Yayınları, 2008.

Cici, Recep. "İmamzâde Esad Efendi." TDV İslam Ansiklopedisi, 22. Cilt, 211-212. 
Çadırcı, Musa. "Osmanlı İmparatorluğu'nda Askere Almada Kura Usulüne Geçilmesi: 1846 Tarihli Askerlik Kanunu," Askeri Tarih Bülteni, 18 (1985): 59-75.

Çelik, Yüksel. “Asâkir-i Mansûre Ordusu'nda Talim Sisteminin Değişimi ve Avrupalı Uzmanların Rolü (1826-1839)." Türk Kültürü İncelemeleri Dergisi, 39 (Güz 2008): 87-118.

Çelik, Yüksel. Şeyhü'l-Vüzerâ Koca Hüsrev Paşa: II. Mahmud Devrinin Perde Arkası. Ankara: Türk Tarih Kurumu, 2013.

Çöl, Emin. Bir Erin Anıları: Çanakkale-Sina Savaşları. Ed.: Celal Kazdağlı. İstanbul: Nöbetçi Yayınları, 2009.

Erbay, Halil İbrahim. "Imams in the Reformed Army of Mahmud II: Uniform Regulations from Ottoman Military Archives, c.1827," The Modern Middle East: A Sourcebook for History içinde, Ed.: C. M. Amin, B. C. Fortna ve E. Frierson. Oxford: Oxford University Press, 2006.

Erdem, Hakan. "Recruitment for the 'Victorious Soldiers of Muhammad' in the Arab Provinces, 1826-1828," Histories of the Middle East: New Directions içinde. Ed.: I. Gershoni, H. Erdem ve U. Woköck. Londra: Lynne Reinner Publishers, 2002.

Erik J. Zürcher, "Little Mehmet in the Desert: The Ottoman Soldier's Experience," Facing Armageddon: The First World War Experienced içinde. Ed.: H. Cecil ve P. Liddle. Londra: Leo Cooper, 1988.

Es'ad Efendi. Üss-i Zafer (Yeniçeriliğin Kaldırılmasına Dair). Ed.: Mehmet Arslan. İstanbul: Kitabevi, 2005.

Green, Nile. Islam and the Army in Colonial India. Cambridge: Cambridge University Press, 2009.

Gülsoy, Ufuk. Osmanlı Gayrimüslimlerinin Askerlik Serüveni. İstanbul: Simurg Yayınları, 2000.

Hanioğlu, M. Şükrü. Preparation for a Revolution: The Young Turks, 19021908. Oxford: Oxford University Press, 2001.

Heinzellman, Tobias. Cihaddan Vatan Savunmasına: OsmanlıImparatorluğu'nda Genel Askerlik Yükümlülüğ̈̈, 1826-1856. Çev.: Türkis Noyan. İstanbul: Kitap Yayınevi, 2009.

Heyd, Uriel. "The Ottoman Ulema and Westernization in the Time of Selim III and Mahmud II," The Modern Middle East: A Reader içinde. Ed.: A. Hourani, P. Khoury ve M.C. Wilson. Berkeley: University of Ca- 
lifornia Press, 1993.

Hüseyin Hakkı. Osmanlı Efradının Takviye-i Maneviyatı. İstanbul: Reşadiye Matbaası, 1914. İmamı Birgivî. Risâle-i Birgivî (Müminlere Nasihat). İstanbul: Bedir Yayınevi, 1964.

Kara, İsmail. "Cumhuriyet Devrinde Askere Din Dersleri: 'İyi Asker İyi Müslüman, İyi Müslüman İyi Asker Olur'.” Toplumsal Tarih, 166 (Ekim 2007): 48-53.

Kazıc1, Ziya. “Alay,” TDV İslam Ansiklopedisi. 2. Cilt, 347-348.

Leonhard, Jörn. "Nation-building, War Experiences, and European Models: The Rejection of Conscription in Britain." Fighting for a Living: A Comparative History of Military Labour, 1500-2000 içinde. Ed.: Erik

J. Zürcher. Amsterdam: Amsterdam University Press, 2013.

Levy, Avigdor. "The Contribution of Zaporozhian Cossacks to Ottoman Military Reform: Documents and Notes." Harvard Ukranian Studies, 6 (3) (Eylül 1982): 372-413.

Levy, Avigdor. "The Ottoman Ulema and the Military Reforms of Sultan Mahmud II." Asian and African Studies, 7 (1971): 13-39.

Levy, Avigdor. “The Military Policy of Sultan Mahmud II, 1808-1839” Doktora Tezi, Harvard Üniversitesi, 1968.

Ömer Fevzi. Maneviyat-ı Askeriye Makaleleri. İstanbul: Mekteb-i Harbiye Matbaas1, 1911.

Ömer Fevzi, Osmanlı Efradına Maneviyat-ı Askeriye Dersleri: Maneviyat Askerin Ruhudur. İstanbul: Mekteb-i Harbiye Matbaası, 1909.

Özcan, Abdülkadir. “Asâkir-i Mansûre-i Muhammediye.” TDV İslam Ansiklopedisi, 3. Cilt, 457-458.

Özkul, Osman. “III. Selim Döneminde Osmanlı Ulemâsı ve Yenileşme Konusundaki Tutumları (1789-1807)” Doktora Tezi, İstanbul Üniversitesi, 1997.

Sözeri, Mustafa Sabri. “Dünya Ordularında Din Terbiyesi ve Teşkilatı.” İstanbul Yüksek İslam Enstitüsü Dergisi, 2 (1964): 93-164.

Sunar, Mehmet Mert. Cauldron of Dissent: A Study of the Janissary Corps, 1807-1826 Doktora Tezi, Binghamton New York Eyalet Üniversitesi, 2006

Sunata, İ. Hakkı. Gelibolu'dan Kafkaslara: Birinci Dünya Savaşı Anılarım. İstanbul: İş Bankası Kültür Yayınları, 2003. 
Süleyman Nuri. Uyanan Esirler: Çanakkale Siperlerinden TKP Yönetimine. İstanbul: Türkiye Sosyal Tarih Araştırma Vakfi, 2002.

Şakul, Kahraman. "Nizâm-1 Cedid Düşüncesinde Batılılaşma ve İslami Modernleşme," Dîvân: İlmî Araştırmalar Dergisi, 19 (2005/2): 117-150.

Şimşek, Veysel. “Osmanlı İmparatorluğu'nda Düzenli Ordu için Asker Toplanmas1: 1826-1853.” Toplumsal Tarih, 198 (2010): 39-40.

Şimşek, Veysel. The Grand Strategy of the Ottoman Empire, 1826-1841, Doktora Tezi, McMaster Üniversitesi, 2015.

Tut, Faruk. Osmanlılar'da Imam-Hatiplik Müessesesi, Yüksek Lisans Tezi, Marmara Üniversitesi, 1991.

Türk Silahlı Kuvvetler Tarihi, 3. Cilt, 5. Kısım: 1793-1908. Ankara: Genelkurmay Basımevi, 1978.

Uzunçarşı11, İsmail Hakkı. "Sultan III. Selim ve Koca Yusuf Paşa.” Belleten, 19 (154) (Nisan 1975): 233-256.

Uzunçarşı11, İsmail Hakkı. Osmanlı Devleti Teşkilâtından Kapıkulu Ocaklarl, I. Cilt: Acemi Ocăğ ve Yeniçeri Ocağl. Ankara: Türk Tarih Kurumu Basımevi, 1988.

Ülker, Mustafa Birol. “Askeri İmamlar.” Tarih ve Medeniyet Dergisi, 61 (Nisan 1999): 61-62.

Ülker, Mustafa Birol. “Tabur İmamlığından Moral Subaylığına.” Çanakkale 2015, 6 (Ağustos 2010):18-25.

Ünal, Uğur. Sultan Abdülaziz Devri Osmanlı Kara Ordusu (1861-1876). Ankara: Genelkurmay Basımevi, 2008.

Üryanizade Ali Vahid. Askerin İlmihali. İstanbul: Ahmed İhsan ve Şürekası, 1917.

Yengin, Sami. Drama'dan Sina-Filistin'e Savaş Günlüğ̈̈ (1917-1918). Ankara: Genelkurmay Basımevi, 2007.

Yeşil, Fatih. Nizâm-ı Cedid'den Yeniçeriliğin Kaldırılışına Osmanlı Kara Ordusunda Değişim, 1793-1826, Doktora Tezi, Hacettepe Üniversitesi, 2009.

Yıldız, Gültekin. "Kara Kuvvetleri." Osmanlı Askerî Tarihi: Kara, Deniz ve Hava Kuvvetleri, 1792-1918 içinde. Ed.: G. Yıldız . İstanbul: Timaş Yayınları, 2013.

Yıldız, Gültekin. "Ondokuzuncu Yüzyılın İki 'Standardizasyon Ütopyası': Kışla ve Hücre Tipi Hapishane.” Türkiye Günlüğ̈̈, 112 (Güz 2012): 
118-135.

Yıldız, Gültekin. Neferin Adı Yok: Zorunlu Askerliğe Geçiş Sürecinde Osmanl Devleti'nde Siyaset, Ordu ve Toplum (1826-1839). İstanbul: Kitabevi, 2009.

Yüksel, Emrullah. "Birgivî.” TDV İslam Ansiklopedisi, 6. Cilt, 191-194.

Zürcher, Erik J. "The Ottoman Conscription System in Theory and Practice, 1844-1918." Arming the State: Military Conscription in the Middle East and Central Asia içinde. Ed.: Erik J. Zürcher. Londra: I.B. Tauris, 1999.

\section{Internet Kaynaklart}

http://mushaf.diyanet.gov.tr/, Erişim tarihi 16.01.2016. 